\title{
AGÊNCIAS REGULADORAS
}

\section{MARCOS JURUENA VILlELA SOUTO}

1. As agências autônomas na Reforma do Estado - 2. Distinção entre agência reguladora e agência executiva - 3. Função regulatória - 3.1. Noção de Regulação - 3.3. A regulação como instrumento da Desestatização - 3.3. A regulação no Brasil - 3.3.1. A regulação sem órgãos reguladores independentes -3.3 .2 . A regulação por agências reguladoras - 4. Natureza jurídica da agência reguladora - 5. Criação e extinção da agência reguladora - 5.1. Criação e extinção da agência - 5.2. Impacto da extinção sobre os contratos - 6. Competência da agência reguladora - 6.1. Conflitos de competências - 6.2. Conflitos entre agências que exercem o poder concedente - 7. Estrutura da agência reguladora - 8. Dirigentes e Pessoal da agência reguladora - 8.1. Regime jurídico dos dirigentes - 8.2. Perda do cargo de dirigente 8.3. Composição de quadros - 9. Receita do órgão regulador - 9.1. Natureza jurídica da taxa de regulação - 10. Contratos celebrados pela agência de regulação - 11. Fiscalização sobre a agência de regulação - 12. Processo administrativo - 13. As agências no âmbito federal 13.1. Petróleo - 13.2. Telecomunicaçōes - 13.3. Energia Elétrica 13.4. Transportes - 14. As agências no âmbito estadual - 14.1. Estado do Rio de Janeiro - 14.2. Estado de São Paulo - 14.3. Estado do Ceará - 14.4. Estado do Rio Grande do Sul-14.5. Estado de Sergipe - 15. Experiências de regulação no Direito Comparado - 16. Conclusão

\section{As agências autônomas na Reforma do Estado}

A crise fiscal do Estado impõe a retomada do equilíbrio orçamentário pela via da contenção do déficit público, forçando uma Reengenharia. Não se trata de cancelar investimentos, remunerar mal serviços e servidores e não honrar a dívida pública. A questão está na qualidade (e não quantidade) do gasto, mudando o modelo de desempenho (gestão), de acordo com um planejamento. 
No Brasil. o "Plano Diretor da Reforma do Estado" visa. entre outros objetivos. a aumentar a capacidade do Estado intervir efetivamente na sociedade e no mercado. dispondo de meios administrativos e financeiros. de modo a não frustrar as expectivas inerentes ao princípio democrático.

Não se trata, apenas, de reestruturar o Estado. Cuida-se de substituir o modelo burocrático de gestão (que enfatiza a legalidade e a racionalidade técnica) pelo modelo gerencial (voltado não só para resultados e não para processos de controle). Daí se falar em avaliação de desempenho (envolvendo o servidor, atribuindo-lhe prêmios, e punindo-o em caso de insuficiência; os ganhos dos servidores estarão condicionados ao desempenho - bônus de desempenho), medição de resultados, de custos e da satisfação do usuário (inclusive com a contratação de pesquisas de opinião pública para verificar a qualidade técnica e comercial e o relacionamento, esclarecimento e comunicação social) com o consumidor.

Para se viabilizar o modelo gerencial, por força do qual dar-se-á atendimento ao princípio constitucional da eficiência, deve haver capacitação de pessoal e informação gerencial. A Emenda Constitucional $\mathrm{n}^{0}$ 19/98, ao dar nova redação ao art.

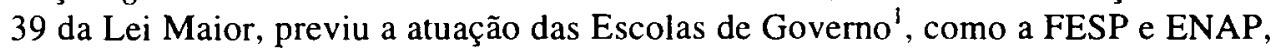
orientando como lidar com a informação. A avaliação de pessoal deve ser vinculada ao sistema de avaliação institucional, com medição de custos, planejamento estratégico (visão de futuro, missão, noção de prioridade e objetivos estratégicos), partindo para o plano operacional.

Foi estabelecida uma diretriz específica para cada tipo de atividade do Estado, a saber:

1 - Núcleo Estratégico, encarregado da formulação de políticas públicas, integrado pela Administração Direta (que seria reduzida, pela alocação de funções nos outros segmentos), além dos Poderes Legislativo e Judiciário; a diretriz é o seu fortalecimento.

2 - Atividades exclusivas, voltadas para a fiscalização, regulação, arrecadação, polícia, que pressupõem o uso de prerrogativas do Estado - a diretriz é instituir um novo modelo, com autonomia, que é das agências autônomas, com novos instrumentos de controle.

3 - Setor de Atividades não exclusivas, como, por exemplo, educação, saúde, cultura, pesquisa, meio ambiente, que devem ser incentivadas pelo Estado, mas não é indispensável que ele administre diretamente tais atividades; daí o surgimento das Organizações Sociais, com autonomia e desvinculadas da Administração Pública, mas sob seu controle. O Projeto "Next Steps" das agências inglesas, no entanto, permite que elas executem ações que podem ser implementadas por entidades privadas. No Brasil, para tais atividades (educação, saúde, pesquisa, cultura) o formato idealizado pelo Plano Diretor da Reforma do Estado é de "organizações sociais". Cite-se aqui, também, as concessões e permissões de serviços públicos.

1 No âmbito da Procuradoria Geral do Estado do Rio de Janeiro, analisamos a competência que deve ser atribuída à Escola de Advocacia do Estado. criada pelo Decreto no 21.037. de 05.12.94 (Informativo da Associação de Procuradores do Estado do Rio de Janeiro $n^{\circ} 3$. Rio de Janeiro. 1998). 
4 - Setor de Atividades que podem ser desenvolvidas pelo mercado. ligadas à produção de bens e serviços; a diretriz é a privatização. restringindo a participação do Estado.

\section{Distinção entre agência reguladora e agência executiva}

O Plano Diretor usou a expressão "agências autônomas", sem fazer distinção entre agências reguladoras, voltadas para a intervenção em mercados específicos regulando a relação entre oferta, com qualidade e preço acessível, e demanda, e agências executivas, ligadas à implementação de política (sem formular políticas, regular ou influir em mercados).

A idéia básica do Ministério da Administração e Reforma do Estado (oriunda da experiência da Reforma Inglesa, além da experiência Americana, Francesa e da Nova Zelândia) era que tivessem unidades da Administração com alto padrão de excelência, com vistas à implementação (e não formulação) de políticas públicas (não executadas por entidades privadas) ${ }^{2}$.

A Agência Executiva é uma autarquia com tratamento especial, isto é, com maior autonomia de gestão, retornando ao conceito original (embora o DL ${ }^{2}{ }^{200 / 67}$ não fizesse a distinção entre atividades exclusivas ou não). Atua em setores de implementação de políticas (tributária, previdência social básica, segurança pública, proteção ambiental, fiscalização). Embora possa "colaborar" com a formulação de políticas, seu papel é de execução.

A ampliação da autonomia gerencial, prevista no art. $37, \S 8^{\circ}$ da Constituição Federal, conforme redação dada pela Emenda Constitucional $\mathbf{n}^{0} 19$, se dá através de um contrato de gestão, com os seguintes elementos (que são condições para que a entidade ou órgão seja transformado em agência executiva):

- Objetivos estratégicos;

- Metas;

- Indicadores de desempenho;

- Condições de Execução;

- Gestão de recursos humanos;

- Gestão de orçamento;

- Gestão de compras e contratos.

A Agência Executiva é, assim, um título jurídico atribuído a um órgão ou entidade, que depende de adesão voluntária, com metas negociadas, compatíveis com os recursos, e não impostas, obedecendo-se às seguintes etapas:

- protocolo de intenções;

- portaria interministerial definindo responsabilidades;

- plano de ações, definindo prazos, recursos;

- elaboração e revisão do planejamento estratégico;

- plano operacional de reestruturação dos processos de trabalho.

2 Segundo relatou ALONSO NUNES no Seminário sobre Agências reguladoras promovido pela FESPFUNDAÇĀO ESCOLA DE SERVIÇO PÚBLICO DO ESTADO DO RIO DE JANEIRO. 
Quanto às agências reguladoras. as primeiras experiências foram do BACEN e do CADE, mas com o processo de desestatização. envolvendo privatizações e concessões, com a nova disciplina legal (que prevê as regulações setoriais), o papel dessas entidades se tornou relevante. como no caso do petróleo, setor elétrico e de telecomunicações.

Não se retira tais agências do Regime Jurídico Único (não mais obrigatório), da Lei de Licitação e da Legislação Orçamentária (Lei n. ${ }^{9}$ 4.320/64); flexibiliza-se muito pouco; há metas, mas não são previstas sanções caso o Estado não assegure a transferência de recursos nos prazos.

\section{Função regulatória}

A regulação não é técnica recente; o que se modificou foi o aperfeiçoamento dos mecanismos para o seu desempenho.

\subsection{Noção de regulação}

VITAL MOREIRA ${ }^{3}$ destaca que o conceito de regulação está longe de consenso entre os autores:

"Começando por referir apenas a regulação estadual da economia, são numerosas e assaz divergentes as definições. Assim, para Mitnick (1980: 7) regulação é o "controlo público administrativo da actividade privada de acordo com regras estabelecidas no interesse público" (public administrative policing of a private activity with respect to a rule prescribed in public interest). Na definição de J. C. Strick (1990: 3), a regulação consiste na "imposição de regras e controlos pelo Estado com o propósito de dirigir, restringir ou alterar o comportamento econômico das pessoas e das empresas, e que são apoiadas por sanções em caso de desrespeito". Para M. Moran (1986: 185) regulação é o sistema pelo qual "a discrição dos indivíduos ou instituições é restringida por meio da imposição de normas (rules)". Segundo Francis (1993: I, 5) a regulação é a "intervenção do Estado nas esferas de actividade privada, para realizar finalidades públicas".

Desde logo, quanto à amplitude do conceito, aparem-nos três concepções de regulação (Jarass, 1987: 77): (a) em sentido amplo, é toda a forma de intervenção do Estado na economia, independentemente dos seus instrumentos e fins; (b) num sentido menos abrangente, é a intervenção estadual na economia por outras formas que não a participação directa na actividade económica, equivalendo, portanto, ao condicionamento, coordenação e disciplina da actividade económica privada; (c) num sentido restrito, é somente o condicionamento normativo da actividade económica privada (por via de lei ou outro instrumento normativo." 
Também acerca do que seja a "regulação", TONY POSNER ${ }^{4}$ destaca que a maioria das definições inclui, em geral, atos de controle e direção de acordo com uma regra, princípio ou sistema. Reflete, pois, normas legais e outras medidas de comando e controle, que contrastam com outras formas de Direito, como o Direito Penal e o Direito Obrigacional. Dos diversos elementos que se extraem dessas definições se detecta a característica de intervenção pública que afeta a operação de mercados através de comandos e controle, que podem ser delegados a sistemas de "auto-regulação". Na visão dos economistas, é uma intervenção estatal em decisões econômicas das empresas, normalmente vista como um ato de política de restrição de mercados.

$\mathrm{Na}$ verdade, a regulação deve ser considerada sob três aspectos, a saber, a regulação de monopólios, em relação aos quais devem ser minimizadas as forças de mercado através de controles sobre os preços e a qualidade do serviço, regulação para a competição, para viabilizar a sua existência e continuidade, e regulação social, assegurando prestação de serviços públicos de caráter universal e a proteção ambiental.

\subsection{A regulaçāo como instrumento da Desestatização}

O tema passou a assumir maior relevância com o processo de privatização na Inglaterra.

Seu primeiro propósito foi proteger o consumidor contra a ineficiência, os altos preços, excesso de lucros, o que, a princípio, só teria solução através da competição, prevenindo os malefícios dos monopólios nos casos em que a competição fosse restrita ou inviável. Buscou-se, ainda, compatibilizar satisfação do consumidor com eficiência econômica.

Com a transferência de funções de utilidade pública, do setor público para o privado, pela via de contratos de concessão, o objetivo da função regulatória é fazer essa transferência interessante para as três partes envolvidas - concedente, concessionário e usuário.

Para tornar o serviço acessível ao usuário e remunerar os elevados investimentos, é preciso diluir a cobrança das tarifas em contratos de longo prazo. Ocorre que, raramente, os contratantes terão capacidade de, no momento da negociação ou da estipulação das condições e obrigações, conhecerem e prevenirem todas as situações que podem ocorrer no futuro. Isso realça o papel do agente regulador, que deve buscar interpretar, de forma isenta, os princípios que orientaram a celebração do contrato, para propor soluções através de mediação e, em caso de insucesso, de arbitragem.

A regulação se desenvolve de acordo com os seguintes princípios ${ }^{5}$ :

4 Law and the regulators. Oxford: Claredon Press, 1997, págs. 3 a 7.

5 DAVID ZILBERSTEIN. Palestra no Seminário Regulaçāo e Competição: O Brasil na modernidade do setor de petróleo e gás, promovido pela Fundaçāo Getúlio Vargas, Federação das Indústrias do Estado do Rio de Janeiro e Jornal do Brasil, em 13.11.98 no Teatro do SESI - Rio de Janeiro. 
- mercado regulado para a competição;

- Estado-intervencionista ou Estado-regulador;

- criação de agências setoriais de regulação, dotadas de autonomia e especialização;

- atenção aos monopólios naturais;

- ambiente de transição, cabendo ao Estado supervisionar o poder de mercado dos operadores e organizar a entrada de novos operadores, zelar pela implantação de um novo modelo organizacional, arbitrar conflitos e completar o processo de regulação normativa;

- garantia do interesse público.

Os Princípios da Regulação exigem preocupação com monopólios naturais; os órgãos reguladores não devem formular políticas setoriais, devendo ser dotados de independência e autonomia. Sua função é regular segmentos do mercado e serviços públicos, protegendo o consumidor, garantindo a livre escolha, o abastecimento (garantia da oferta dos serviços) e preços acessíveis.

É claro que a idéia é sempre harmonizar o interesse do consumidor, na obtenção do melhor preço e da melhor qualidade do serviço, com os do fornecedor do serviço, que deve ter preservada a viabilidade da sua atividade, como forma de se assegurar a continuidade do atendimento dos interesses sociais.

Daí porque a prevenção dos conflitos é um dos principais aspectos da regulação, através da elaboração de diretrizes que traduzem os conceitos de eficiência técnica e financeira para o caso concreto do segmento regulado. É claro que tais diretrizes se fazem dentro de um chamado "marco regulatório", que é composto pela lei, regulamento, edital de licitação e contrato firmado com o Poder Público. Na definição da GLÓRIA CONFORTO ${ }^{6}$ :

"O marco regulatório é o conjunto de regras, orientações, medidas de controle e valoração que possibilitam o exercício do controle social de atividades de serviços públicos, gerido por um ente regulador que deve poder operar todas as medidas e indicações necessárias ao ordenamento do mercado e à gestão eficiente do serviço público concedido, mantendo, entretanto, um grau significativo de flexibilidade que permita a adequação às diferentes circunstâncias que se configuram."

Não há, pois, qualquer violação ao princípio da legalidade, eis que as agências reguladoras têm sua função e competência definidas na lei, nada podendo exigir além dos limites que lhe são por ela autorizados. Pelo princípio da legalidade no direito brasileiro, "ninguém será obrigado a fazer ou deixar de fazer alguma coisa senão em virtude de lei” (CF, art. $5^{\circ}, \mathrm{II}$ ), o que se reforça pelo princípio da legalidade administrativa, por força do qual a Administração só pode agir se devidamente autorizada por lei (CF, art. 37) e, no direito brasileiro, as agências reguladoras integram a Administração Pública (assumindo, na maioria dos casos, a forma autárquica) ou recebem delegação legal para a regulação. Em outras palavras, não só o particular é livre para agir até que a lei o diminua tal liberdade, como a Administração

6 Descentralização e regulaçāo da gestão de serviços públicos. Revista de Administração pública vol $32 \mathrm{n}^{\mathrm{Q}}$ 1. Rio de Janeiro, 1998 , págs. 27 a 40 
só está autorizada a agir quando houver interesse público reconhecido em lei impondo-lhe o dever de agir.

Em síntese, como leciona VITAL MOREIRA, um processo de regulação implica, tipicamente, nas seguintes fases: formulação das orientações da regulação; definição e operacionalização das regras (como leis, regulamentos, códigos de conduta); implementação e aplicação das regras (autorizações, licenças, injunções, e, no Brasil, cite-se, ainda, as concessões); controle da aplicação das regras; sancionamento dos transgressores; decisão dos recursos. Tendo poderes normativos, executivos e parajudiciais, a regulação deve ficar a cargo de comissões reguladoras independentes.

\subsection{A regulação no Brasil}

\subsubsection{A regulação sem órgãos reguladores independentes}

O artigo 174 da Constituição Federal brasileira já previa a função reguladora do mercado pelo Estado.

Até a execução dos Programas de Desestatização, a regulação era desenvolvida no âmbito do Banco Central e do CADE, e da utilização de estoques reguladores do Estado para intervenção como instrumento de política agrícola e o uso de tributos.

$\mathrm{Na}$ política industrial e na política de comércio exterior, por exemplo, cite-se a utilização do imposto de importação para desestimular ou estimular condutas, ora incentivando a produção nacional a ganhar os mercados interno e externo, ora para estabelecer condições de competitividade e melhoria das condições de qualidade e preço em função da oferta de gêneros estrangeiros. Aumenta-se o imposto de exportação, de circulação de mercadorias ou de produtos industrializados para garantir o abastecimento do mercado interno ou, por exemplo, para estimular a industrialização de produtos semi-acabados (evitando que o País volte ao tempo de colônia, que exportava matéria-prima barata e importava o produto industrializado); isso, no entanto, significa exportar tributo, tornando o produto menos acessível no mercado externo. Eleva-se o imposto sobre a propriedade para desestimular latifúndios improdutivos ou áreas urbanas não edificadas.

No âmbito da política monetária, a majoração de alíquotas do IOF serve para retirar o excesso de moeda no mercado (nessa mesma linha, aliás, o Banco Central compra ou vende moeda estrangeira para dar estabilidade à moeda nacional, eleva o depósito compulsório dos bancos também para reduzir o excesso de liquidez). A Comissão de Valores Mobiliários - CVM também exerce uma função de regulação, fiscalização e supervisão dos mercados de títulos e contratos de investimentos coletivos (Medida Provisória n $1.742-15$, de 11.03 .99 (D. O. U. Parte I, de 12.03.99, pág. 9).

Cite-se, ainda, as funções regulatórias exercidas pelo setor privado, como é o caso do CONAR - Conselho Nacional de Auto-regulamentação Publicitária e também na indústria cafeeira, que instituiu o selo do Café, objetivando distinguir o produto de qualidade dos demais. 


\subsubsection{A regulação por agências reguladoras}

A regulação só passou a ser atribuída a entidades independentes ${ }^{7}$ a partir de 1997, com a criação das agências de regulação nos setores de energia, petróleo e telecomunicações; este setor, aliás, o único que teve previsão constitucional da existência de um órgão regulador $\left(E C \mathrm{n}^{0} 8\right.$, de 15.08 .95 , que deu nova redação ao art. 21, XI, da Constituição Federal, flexibilizando o monopólio das telecomunicações).

No Brasil, a citada independência dos órgãos reguladores é relativa, posto que vigora o "princípio da jurisdição una, o que implica em dizer que "nenhuma lesão ou ameaça de lesão escapará à apreciação do Poder Judiciário". Essa submissão das decisões das agências reguladoras ao magistrado diminui-lhes a força e a eficácia de agilizar o procedimento, solucioná-lo através da intervenção de técnicos habilitados e reduzir os custos do contencioso. $O$ ideal era introduzir a limitação da Lei no 9307 (que regula a arbitragem), somente admitindo o questionamento jurisdicional se houver vícios formais na decisão, respeitadas as situações em que há direitos indisponíveis do Estado. Também macula a independência da agência a admissão de recurso de suas decisões para autoridade do Poder Executivo (controle administrativo).

Na lição de PEDRO DUTRA ${ }^{8}$ :

"Quatro fatores concretos contribuíram para definir o modelo moderno das agências reguladoras. O primeiro, a necessidade de decisões em tempo econômico, dirimindo conflitos entre prestadores e entre estes e usuários. Setores como os de serviços públicos demandam altos investimentos de instalação e de manutenção e a solução tardia de conflitos vulnera investimentos e compromete o devido atendimento ao consumidor. O segundo fator é a habilitação técnica da agência, que lhe permita enfrentar a complexidade inerente aos serviços regulados, inclusive exigindo dos prestadores obediência às inovações tecnológicas. O terceiro é de ordem econômica: a tensão a ser permanentemente dominada, entre a tendência ao monopólio natural, inerente a esses serviços, e o fato de eles deverem ser prestados em um regime constitucional de livre mercado. O quarto fator opera no plano jurídico: aqui a tensão se acha na conciliação do interesse público, imantado pelo conjunto dos consumidores, e o interesse privado, manifestado nas empresas prestadoras dos serviços.

A eficiência de uma agência reguladora será medida pelo funcionamento harmônico desses seus elementos inexos, e também pelo estrito cumprimento das regras legais que lhe disciplinam a ação.

Esta se desdobra em três planos, objetivos e complementares entre si: a edição de regras específicas, destinadas aos prestadores de serviço e aos consumidores, a

7 A independência se dá em função do respaldo político da nomeação aprovada pelo Poder Legislativo, pelo mandato fixo dos dirigentes e pelo fluxo natural dos recursos para custeio, arrecadados junto aos atores fiscalizados sem.

8 A fiscalização dos serviços públicos privatizados. Rio de Janeiro: Gazeta Mercantil, 20.10.98, pág. A-3. 
fiscalização do cumprimento dessas regras, dos contratos específicos e da lei, por parte dos prestadores. e, por fim a repressão à violação das regras legais, das obrigações contratuais e das normas regulatórias pelos prestadores de serviço."

\section{Natureza jurídica da agência reguladora}

Como se disse, a regulação deve ser atribuída a autoridade independente, que, no entanto, exerce poderes típicos do Estado, legitimado que está para intervir no domínio econômico.

No Brasil, a atividade econômica é instrumento para a obtenção do desenvolvimento econômico, objetivo da República $\left(\mathrm{CF}\right.$, art. $\left.3^{\circ}\right)$, por força da qual se atingirá o pleno emprego, o respeito à dignidade humana e o bem-estar de todos; daí ser o Estado legitimado pela Lei Maior para atuar sempre que o interesse público justificar uma restrição da livre iniciativa em prol da coletividade (observados os limites e os objetivos constitucionais para tal intervenção).

Formulada a política pública, seu acompanhamento é outorgado, por lei, à agência reguladora, que atua no campo da ação exclusiva do Estado; em outras palavras, a agência executa uma ação que pode implicar na restrição da liberdade empresarial em prol do interesse coletivo.

Tal restrição somente deve ser executada concretamente por pessoa jurídica de direito público, o que, aliado à autonomia para o desempenho dessa função, justifica, no direito brasileiro, a adoção da forma autárquica como a ideal para a descentralização da regulação estatal.

\section{Criação e extinção da agência reguladora}

Como características básicas da agência reguladora, destaca ISAAC BENJÓ $\mathrm{NETO}^{9}$ que, em primeiro lugar, as metas estabelecidas para orientar a agência devem incluir a disponibilização dos serviços básicos para todos os cidadãos, com preços justos e estimulando condições competitivas e inovações técnicas; em segundo, a independência das decisões; em terceiro, a flexibilidade organizacional do quadro funcional, para permitir adequações de acordo com as evoluções do mercado.

SÉRGIO NELSON MANNHEIMER ${ }^{10}$ aponta os seguintes aspectos a serem considerados na criação de uma agência reguladora:

9 The role of regulatory agencies in the brazilian privatization process: A conceptual approach for the public utilities companies. Original apresentado, em Dezembro de 1996, a The George Washington University - IBI - Insitute of Brazilian Business \& Public Management Issues - The Minerva Program. 10 Agências estaduais reguladoras de serviços públicos. Revista Forense vol 343 págs. 221 a 233 . Rio de Janeiro: Forense. Tese apresentada no XXIII Congresso Nacional de Procuradores de Estado realizado em novembro de 1997 na cidade de São Luís - Maranhão. 
a) modelo institucional, definindo se o órgão deverá se ocupar de todos os setores (como ocorre no âmbito estadual) ou se haverá um órgão específico para cada um (modelo adotado na esfera federal);

b) independência. assegurando um fluxo de recursos que garanta o funcionamento da agência sem a ingerência de terceiros. liberação da política salarial da agência em relação às demais entidades da Administração Pública, colegiado superior composto de membros estáveis;

c) critério de eficiência na escolha dos conselheiros, que devem ter reputação ilibada e qualificação profissional na área objeto da regulação, com mandato fixo e desvinculado dos mandatos políticos.

\subsection{Criação e Extinção da agência}

Conforme dispõe o artigo 37, XIX, da Constituição Federal, a autarquia é criada por lei; por representar uma opção discricionária de descentralização de uma função regulatória, tal lei deve ser de iniciativa privativa de quem detém a direção superior da Administração (CF, art. 84, II c/c 61, § $1^{\circ}$, II, e). O mesmo se diga quanto à extinção, cujo juízo de conveniência e oportunidade se inclui no exercício do poder hierárquico do administrador apenas no que concerne à estruturação das funções executivas (o que implica em dizer que não se pode invocar o poder de direção superior da Administração para interferir nas decisões dos agentes reguladores, que, como dito e repetido, devem se pautar pela independência em relação ao Poder Público). A extinção deve ser motivada por um interesse público relevante e não pela impossibilidade de o poder concedente interferir nos julgamentos do regulador independente.

\subsection{Impacto da extinção sobre os contratos}

A independência que caracteriza a agência reguladora é fator essencial para a decisão dos agentes econômicos de atuar nos setores regulados.

Especialmente nos países em desenvolvimento, há uma grande resistência em litigar com o Poder Público quer na esfera administrativa quer nos tribunais.

No contencioso administrativo, a Administração é, a um só tempo, parte e julgador, de pouco adiantando, aos olhos do investidor, a posição doutrinária no sentido de que o interesse público por ela representado é o atendimento imparcial do princípio da legalidade; afinal, a praxe é o corporativismo, por força do qual dificilmente os processos administrativos concluem pelo erro da Administração.

No Judiciário, além do acúmulo de processos e dos elevados custos, contribui para a demora da decisão o tratamento processual diferenciado atribuído à Fazenda Pública (que inclui prazos em quádruplo para contestar, em dobro para recorrer, o 
duplo grau obrigatório de jurisdição quando a decisão lhe for desfavorável, a impenhorabilidade dos bens públicos. forçando a execução através do sistema de precatórios, pagos apenas no exercício financeiro subseqüente. sem atualização ou reajuste, obrigando a renovação do instrumento requisitório da verba orçamentária), além do elevado número de recursos cabíveis das decisões até o trânsito em julgado.

Esses fatores desencorajavam os investimentos, que são de alto vulto e de retorno em longo prazo.

A necessidade desses recursos privados, em substituição aos públicos (insuficientes ou inexistentes), forçou a previsão contratual dos órgãos reguladores independentes.

É certo, por um lado, que não se pode opor o entendimento de que "a lei não prejudicará o ato jurídico perfeito" ( $\mathrm{CF}$, art. $5^{\circ}, \mathrm{XXXVI)}$ para assegurar a manutenção do órgão regulador para os contratos em que sua atuação foi prevista, impedindo, em relação a estes, os efeitos da lei que o extingue; isso significaria sustentar que o interesse privado do investidor supera o interesse público expresso na lei no sentido da necessidade de se reestruturar a função executiva através de outro órgão ou entidade da Administração.

Por outro lado, não é menos exato que se trata de uma típica situação de "fato do príncipe", que, imprevisível às partes no momento da contratação, autoriza a aplicação da Teoria da Imprevisão para ensejar o direito do particular, no caso de contrato de concessão (exemplo mais comum no Brasil), a pleitear a resolução do contrato de pleno direito.

O contrato gera para o particular o direito de ter uma política independente de regulação - embora não the seja assegurada a preservação do mesmo agente regulador.

Assim, se a agência reguladora é extinta, mas suas funções são atribuídas a outro órgão ou entidade que atuem com o mesmo grau de independência, não é legítima a tese de extinção pela Teoria da Imprevisão, mas o será se as funções forem exercidas dentro da Administração direta ou submetidas ao poder hierárquico do administrador (pressupondo a direção, a delegação, a revisão e a avocação de tarefas). O mesmo se diga se houver delegação de competência de um órgão regulador federal dotado de autonomia para uma órgão estadual ou municipal que não tenha tal atributo.

De qualquer sorte, a extinção de agências reguladoras não pode ser exercida em desacordo com os princípios inerentes à Administração Pública, em especial, os da impessoalidade e da moralidade. Não se pode extinguir uma agência reguladora, por exemplo, pelo fato de seus conselheiros terem investidura inicial pelo anterior governante, de modo a que o sucessor não possa, em seu mandato, fazer novas investiduras. Dentro do mesmo exemplo, seria imoral a ampliação do número de vagas apenas para viabilizar tal capricho político.

O princípio da segurança jurídica busca atender ao valor "segurança" que o ordenamento jurídico se propõe a tutelar, evitando riscos que só reduzem os investimentos tão necessários para o abastecimento de bens e serviços que a sociedade reclama. 
Enquanto no plano federal as agências de energia. petróleo e telecomunicações exercem funções de poder concedente, estabelecendo as condições em que se dará a transferência para a iniciativa privada, no âmbito dos estados, as agências só atuam numa etapa posterior, regulando, fiscalizando, mediando, arbitrando os conflitos, dentro das respectivas áreas de atuação (observada, pois, a partilha constitucional de competências entre União, Estados, Municípios e Distrito Federal, bem como relativamente ao serviço ou setor regulado).

\subsection{Conflitos de competências}

Há, contudo, inúmeras situações que implicarão em conflitos de competência entre Poderes federal, estadual e municipal, que dependerão de decisão em esfera alheia aos respectivos órgãos reguladores. Por exemplo, a Lei n. ${ }^{0} 9433$ estabelece princípios do uso da água para solucionar o conflito histórico entre os usuários, resguardada a competência para a União legislar sobre energia. O potencial hidrelétrico é dado pela Agência Nacional de Energia Elétrica - ANEEL, mas a vazão é ditada pelo Conselho Nacional de Recursos Hídricos.

O mesmo conflito existe, em matéria de gás para instalação de termoeléctricas, envolvendo competências da Agência Nacional do Petróleo - ANP e da ANEEL. Ainda em matéria de gás, conflitos entre a União, competente para as atividades de transporte, e o Estado, competente para o serviço público de distribuição de gás canalizado.

$\mathrm{Na}$ linha dos conflitos entre entidades federadas, a discussão em sede de serviços de saneamento, envolvendo os Estados, que são titulares das águas, e os municípios, que se intitulam competentes para os serviços locais de distribuição da água $e$ captação do esgoto" .

Cite-se, ainda, os serviços de telecomunicações com uso de linhas e torres de energia elétrica, que pode envolver as competências da ANEEL com a Agência Nacional de Telecomunicações, ou as competências da ANATEL e de fiscais de posturas municipais quanto ao local de instalação das torres.

Cabe, também, mencionar o conflito entre as agências reguladoras e o Conselho Administrativo de Defesa Econômica - CADE, eis que, em matéria de concessões estatais, está-se diante de monopólios ou oligopólios ${ }^{12}$. Nesse passo, a Lei que instituiu a ANATEL previu a competência do CADE para processar as infrações de

11 Tratamos do tema em Desestatização - Privatização, Concessões e Terceirizações. Rio de Janeiro: Lumen Juris, 1999, págs. 227 a 234.

12 Nosso entendimento, em estudo denominado Monopólios e concentraçōes econômicas no setor público, é no sentido de que o CADE não pode sobrepor seu juízo técnico a decisões de natureza política sobre a forma de desestatização da atividade. 
abuso de poder econômico que forem comunicadas pela agência, o que, por óbvio, não a impede de estruturar o setor estabelecendo oligopólios e monopólios onde eles se justificarem.

O CADE, como o Judiciário, é órgão de Estado que exerce um controle técnico em áreas sujeitas à livre iniciativa, o que não é o caso das concessões, sujeitas a um monopólio constitucional estatal; quando muito, pode, por sua Procuradoria, agora dotada de legitimidade ativa, ajuizar ação civil pública quando a livre concorrência (elevada à categoria de interesse difuso) for violada (frisando que os serviços públicos foram retirados, pela sociedade, da esfera da livre iniciativa e concorrência).

Quando o conflito envolver entidades da mesma esfera de poder da Federação, a solução deve se dar no exercício do poder hierárquico do administrador; se entre entidades de unidades distintas da Federação, somente o Supremo Tribunal Federal poderá decidir quem tem a competência.

\subsection{Conflitos entre agências que exercem o poder concedente e a concessionária}

Um dos relevantes papéis desempenhados pelas agências reguladoras é a solução de conflitos entre os atores envolvidos na concessão. $O$ problema surge quando a agência é um desses atores, exercendo a função de poder concedente, hipótese em que é desconfortável, aos olhos do investidor, que ela atue como parte e julgador ao mesmo tempo.

Como, em matéria de concessões de serviços públicos, a Lei de Concessões previu a possibilidade de serem estabelecidos meios amigáveis de solução de controvérsias, muito se tem discutido acerca da possibilidade de adoção do mecanismo da arbitragem.

A questão seria de simples deslinde, não fosse a legislação pátria sobre arbitragem - Lei $\mathrm{n}^{0}$ 9.307, de 23.09.96 - sobre questões comerciais, nela não abrangidos os contratos administrativos.

Assim, embora polêmica a matéria, já tivemos oportunidade de $\operatorname{citar}^{13}$ ensinamento de DIOGO DE FIGUEIREDO MOREIRA NETO, que, valendo-se de orientação jurisprudencial calcada em voto do Ministro GODOY ILHA, do extinto Tribunal Federal de Recursos, no sentido de que restringir o uso da arbitragem pelo Estado é restringir-lhe a própria autonomia contratual e a possibilidade de prevenir litígios e solucionar conflitos pela via do pacto de compromisso, desde que não estejam envolvidos interesses indisponíveis. Vale citar o exemplo dos contratos de financiamento firmados com o Banco Internacional de Reconstrução e Desenvolvimento - BIRD, que adotam tais cláusulas de previsão de arbitragem.

Em matéria de concessões de petróleo, há doutos entendimentos no sentido de que os recursos do subsolo, não sendo bens de uso comum do povo nem de uso especial das repartições administrativas nem aplicáveis aos serviços públicos, são bens dominicais e, portanto, na sua utilização o Estado se equipara ao particular, 
celebrando contratos regidos predominantemente pelo direito privado, admitida, pois, a arbitragem comercial para solucionar os litígios decorrentes dessas pactuações $^{14}$. Ressalte-se a lição de MARCELO OLIVEIRA MELLO ${ }^{15}$ no sentido de serem os pactos de petróleo definidos mundialmente como contratos sui generis, ou, mais especificamente, contratos econômicos, aos quais a arbitragem se aplicaria perfeitamente.

\section{Estrutura da agência reguladora}

A autonomia se dá pela existência de mandatos fixos não coincidentes entre si nem com o ciclo eleitoral; deve ter receita própria; deve estar isenta das regras salariais do setor público (que estrangulam a remuneração) e seus dirigentes devem passar por um período de "quarentena".

As agências reguladoras devem ter um Conselho Diretor, com cinco conselheiros, uma Secretaria Executiva, Câmaras Técnicas especializadas e uma Ouvidoria, para tratar de relações dos usuários com os concessionários, após os serviços de

14 Vide, por ex., o Contrato de concessão de petróleo celebrado entre a ANP e a PETROBRÁS: Cláusula Vigésima-Nona - Regime Jurídico - Lei Aplicável 29.1 - Este Contrato será executado, regido e interpretado de acordo com as leis brasileiras, que serão rigorosamente cumpridas pelo Concessionário no exercício dos seus direitos e na execução de suas obrigaçōes aqui previstas. 29.2 Foro - Fica eleito o foro da Cidade do Rio de Janeiro para resolver quaisquer dúvidas, controvérsias, conflitos ou pendências surgidos entre as partes em decorrência da execuçāo ou da interpretaçāo deste Contrato, que nāo possam ser solucionados de forma amigável ou por meio de arbitragem. Conciliação - 29.3 As Partes envidarão todos os esforços no sentido de resolver entre si, amigavelmente, toda e qualquer disputa ou controvérsia decorrente deste Contrato ou com ele relacionada. Poderão também, desde que firmem acordo unânime por escrito. recorrer a perito internacional, para dele obter um parecer fundamentado que possa levar à superação da disputa ou controvérsia. - 29.3.1 Firmado um acordo para intervenção de perito internacional, nos termos do parágrafo 29.3 , o recurso a arbitragem previsto no parágrafo 29.3 somente poderá ser exercido depois que esse perito tiver emitido seu parecer fundamentado. Arbitragem -29.4 Observado o disposto no parágrafo 29.3.1, se a qualquer momento uma Parte considerar que inexistem condições para uma soluçāo amigável de uma disputa ou controvérsia a que se refere o parágrafo 29.3 , então essa Parte poderá submeter essa disputa ou controvérsia a arbitragem, dando início ao processo respectivo, de acordo com os seguintes princípios: (a) serão três os árbitros, escolhidos um por cada Parte e o terceiro, que exercerá as funçōes de presidente, nomeado de acordo com as Regras especificadas na letra (d); (b) o lugar da arbitragem será a cidade do Rio de Janeiro, Estado do Rio de Janeiro, Brasil; (c) o idioma a ser utilizado no processo de arbitragem será a língua portuguesa, podendo os árbitros, por unanimidade, aceitar depoimentos ou documentos em outro idioma, sem necessidade de traduçāo oficial; (d) a arbitragem se realizará de acordo com as Regras de Conciliação e Arbitragem da Câmara de Comércio Internacional, como em vigor na data de início do procedimento; (e) quanto ao mérito, decidirão os árbitros com base nas leis substantivas brasileiras; (f) o laudo arbitral será definitivo e obrigará as Partes, podendo ser executado perante qualquer juízo ou tribunal competente. Suspensão de Atividades 29.5 Surgida uma disputa ou controvérsia, a ANP decidirá sobre a suspensão ou não das atividades sobre as quais verse essa disputa ou controvérsia, até a solução da mesma, usando como critério para essa decisão a necessidade de evitar risco pessoal ou material de qualquer natureza, em especial no que diz respeito às Operações. Aplicação Continuada 29.6 As disposiçōes desta Cláusula Vigésima-Nona permanecerão em vigor e sobreviverāo à extinção ou rescisão deste Contrato, seja por que motivo for.

15 Apud Desestatização. cit. págs. 163 e 164. 
ouvidoria de cada uma das empresas concessionárias, fiscalizando sua atuação e funcionando como instância recursal. Não é, pois, um órgão de defesa do consumidor, tal como o PROCON.

Os conselheiros são indicados ao Poder Legislativo e, aprovados, são nomeados com mandato fixo, sujeitos à perda apenas nas condições previstas em lei. Os mandatos não devem ser coincidentes. Além da independência técnica dos seus conselheiros, deve a agência ter independência financeira, recebendo seus recursos diretamente das concessões (um percentual das receitas dos concessionários).

\section{Dirigentes e Pessoal da agência reguladora}

A eficiência, a intangibilidade política e a flexibilidade dos quadros são os fatores fundamentais em matéria de pessoal das agências.

\subsection{Regime jurídico dos dirigentes}

A Constituição Federal prevê duas formas de provimento de cargos públicos.

A primeira, mais democrática, através da prévia seleção mediante concurso público de provas ou de provas e títulos, destinada ao provimento de cargos efetivos, que asseguram ao seu titular a estabilidade após o período de três anos e avaliação de desempenho favorável nesse período.

A segunda, destinada ao provimento de cargos de confiança e de funções gratificadas, de livre nomeação e exoneração pelos Chefes de Poder, quanto aos cargos das respectivas estruturas.

Cabe falar, ainda, na contratação excepcional e temporária do art. 37, IX, CF.

Nenhum desses modelos se enquadram na opção adotada pelas leis que instituíram agências reguladoras e estabeleceram processos peculiares de nomeação de seus dirigentes.

A diretoria da agência deve ter legitimidade; daí a indicação pelo Chefe do Poder Executivo, passando pela aprovação do Poder Legislativo; tal critério supera o do concurso público bem como o da livre exoneração; há, contudo, questionamentos ao mandato com prazo fixo, pois, se não há concurso, o cargo seria de confiança e, por isso, demissível a qualquer momento.

Em defesa da constitucionalidade da norma pode ser citado o art. 37, I, CF, que prevê a acessibilidade aos cargos públicos daqueles que preencham os requisitos previstos em lei; se o requisito é a aprovação política de profissional de reputação ilibada e notória especialização no setor regulado, não pode haver perda do cargo senão nas hipóteses na lei autorizadas.

Ademais, o concurso público e os cargos de livre nomeação são critérios para provimentos de cargos reservados aos agentes administrativos, mas não necessariamente aos agentes políticos, que se submetem aos critérios definidos em lei, limitando, assim, a liberdade do administrador na sua exoneração. 
Apreciando a questão, o Egrégio Supremo Tribunal Federal ${ }^{16}$ entendeu que não há plausibilidade jurídica no pedido de suspensão liminar dos efeitos da lei que condiciona a prévia aprovação, pelo Legislativo, dos nomes indicados pelo Poder Executivo, em função do disposto no art. 52, III, $f$, da Constituição Federal (que estabelece competência privativa do Senado Federal para aprovar os titulares de cargos que a lei determinar).

Mister se faz esclarecer que essa limitação deve ser prevista em lei de iniciativa do Chefe do Poder Executivo (CF, art. 61, $\S 1^{9}$, II, a), sendo inconstitucional que a norma tenha origem em iniciativa ou emenda de outro Poder.

A lei deve prever que os dirigentes não devem manter, durante o mandato e na quarentena, qualquer vínculo com o concedente, concessionário ou associação de usuários, não devendo deles receber qualquer remuneração. Devem, pois, ser licenciados ou ter seus contratos de trabalho suspensos, sem remuneração, e não "postos à disposição" da agência, conservando seus vencimentos, sob pena de restar mantido o vínculo e a potencialidade de interferência da fonte pagadora.

\subsection{Perda do cargo de dirigente}

Em face da segurança jurídica dos investimentos e da autonomia que deve ser prevista para a agência, os dirigentes só devem perder seus cargos se cometerem falta grave apurada em processo administrativo ou judicial em que sejam assegurados a ampla defesa e o contraditório.

Polêmica, no entanto, é a situação decorrente da extinção da agência por lei de iniciativa do Chefe do Poder Executivo, no sentido de ser ou não mantida a sua remuneração. Em outras palavras, a dúvida é sobre a eventual existência de um direito adquirido à percepção da remuneração após a extinção do cargo.

$\mathrm{O}$ tema ainda não tem precedentes no direito brasileiro, eis que as agências foram recém-criadas (sendo a do Estado do Rio de Janeiro a primeira a ser objeto de tal preocupação).

Há, contudo, paradigmas.

O primeiro deles decorreu da extinção do Conselho Estadual de Cultura, no qual se reconheceu que não havia direito adquirido dos conselheiros a perceber remuneração após a extinção do órgão. Sobre o tema assim se manifestou o Procurador do Estado do Rio de Janeiro PAULO ROCHA LAGOA ${ }^{17}$ :

"A norma pela qual se dá organização a um órgão da Administração Pública limita-se a instituir preceitos genéricos, objetivos e impessoais, através dos quais se estruturam as competências dentro desses órgãos, estabelecem-se as relações que os

16 Ação Direta de Inconstitucionalidade proposta pelo Governador do Estado do Rio Grande do Sul atacando a Lei estadual $n^{2} 10.931 / 97$, arts. $7^{2}$ e $8^{2}$, na redação originária e na alteração dada pela Lei $n^{2}$ 11.292/98. Informativo STF n² 144, de 29 a 30/03/99 e 05 a 09/04/99. Brasília: Supremo Tribunal Federal, 1999.

17 Ofício $n^{9} 17 / 72-P R L$, da Procuradoria Geral do Estado da Guanabara, exarado em 07.06.72 no Processo Administrativo no 03-00.81 1/72. requerido por Modesto Dias de Abreu e Silva. 
mesmos devem ter com os demais componentes da Administração e se instituem, se for o caso, as remunerações devidas aos colaboradores da Administração. Os preceitos em tela não têm por objeto a criação de situações jurídicas individuais, capazes de criar direitos subjetivos, eis que visam apenas outorgar ao novo órgão sua estrutura.

Constituem, dessa forma, simples regras de organização, as quais, ao outorgar competências aos colaboradores da Administração, fazem com que os mesmos adquiram determinado "status", no qual continuam enquanto a norma de organização continuar a existir. O "status", não sendo situação jurídica individual, não vive de per si, decorrendo exclusivamente da norma, enquanto vigorar o feixe de poderes, atribuições e faculdades que lhe são inerentes.

Ora, variando o "status" do colaborador da Administração na medida em que a regra de organização lhe outorgar competência, segue-se não possuir ele direito público subjetivo à sua manutenção nesse mesmo "status", pois dita regra pode, a qualquer momento, ser objeto de revogação ou modificação, desaparecendo por completo o "status" e suas atribuições. Por igual, se era decorrência desse "status" o poder de exigir uma remuneração, esse poder também deve, necessariamente, desaparecer no momento da revogação da norma de organização."

Nessa mesma linha de argumentação se posicionou o Procurador do Estado do Rio de Janeiro EUGÊNIO NORONHA LOPES ${ }^{18}$, invocando precedentes tanto na esfera administrativa (o parecer supra, confirmado em juízo, em 23.07.73, pela $3^{\mathrm{a}}$ Câmara Cível do TJ) como na jurisprudencial (M. S. $\mathrm{n}^{\mathbf{0}}$ 2065, do Eg. TJ/RJ, por acórdão de 3.10.63), segundo o qual não existe direito líquido e certo ao exercício de mandato pelo tempo integral fixado como limite de duração. Instruíram tal ponto de vista pronunciamento do Professor Caio Mário da Silva Pereira, então Consultor Geral da República (20.04.61, publicado na R.D.A 65/248 e nos Arquivos do Ministério da Justiça, vol. 78, fls. 51/59), bem como julgado do Egrégio Supremo Tribunal Federal (M.S. 8693, de 17.11.62 - vol. 85 dos Arquivos do Ministério da Justiça, págs. 208/248), onde se destacava que no poder de nomear conferido ao Chefe do Poder Executivo estava implícito o de demitir, o que não poderia ser ilidido por uma norma infraconstitucional.

O que é interessante ressaltar é que já àquela época se distinguia entre os órgãos autônomos e aqueles estruturados na hierarquia da Administração, não se impedindo ao Poder Executivo de exonerar, livremente, os integrantes destes últimos; havia oposição do Ministro Victor Nunes Leal à aplicação de tal regra aos órgãos que exercessem "funções quase-legislativas ou quase jurisdicionais", criadas por lei e que correspondem latu sensu às autarquias (págs. 219 e 224). É essa, exatamente, a hipótese aqui tratada.

A lei, de iniciativa do Chefe do Poder Executivo, limitou essa liberdade de demitir os dirigentes dessas autarquias especiais, que têm funções administrativas,

18 Ofício n⿳2 21/72-ENL exarado em 05.09.79, nos Processos Administrativos $\mathrm{n}^{2} \mathrm{~s}$ E-0310.769/79 e E-14/002.282/79, atendendo a consulta do Instituto Estadual do Patrimônio envolvendo o Conselho Estadual de Tombamento. 
normativas e arbitrais, assegurando-lhes uma independência que lhes permite, até mesmo, julgar contra interesses políticos ou econômicos, o que é da essência da política regulatória, que, por sua vez, estabelece a indispensável segurança jurídica aos investimentos. Ora, se tal segurança puder vir a ser afastada pela possibilidade de se extinguir o direito dos dirigentes, não resta dúvida que os investimentos de que dependem o desenvolvimento econômico e a adequada prestação dos serviços públicos irão desaparecer.

Daí o paradigma mais próximo ser aquele que reconheceu aos Conselheiros do extinto Conselho de Contas do Estado do Rio de Janeiro o direito a perceber seus vencimentos após a extinção do órgão em função da vitaliciedade a eles inerente no momento da investidura (em que pese nossa discordância desse julgado, em função do curtíssimo espaço de tempo de exercício no cargo e dos elevados vencimentos atribuídos aos seus ocupantes).

Em que pese tal entendimento, no Eg. Supremo Tribunal Federal ficou vencido quanto à questão o eminente Ministro Sepúlveda Pertence ${ }^{19}$, que entende relevante a arguiição de inconstitucionalidade da lei que impede demissão de ocupante de cargo nomeado a termo, tendo em vista o disposto no verbete $\mathrm{n}^{\mathrm{o}} 25$ da Súmula que reconhece inexistir tal impedimento ao Chefe do Poder Executivo.

\subsection{Composição de quadros}

Como dito, a agência deve ser moldada de maneira que possa, com facilidade, adequar-se às constantes evoluções do mercado, valendo-se, portanto, de flexibilidade para a renovação de seus quadros. A estrutura administrativa da Agência deve ser calcada na idéia de que não lhe cabe acumular dados do passado, devendo buscar dados atuais para solução de problemas. A agência tem compromisso com o resultado. Deve ter poucos e qualificados servidores integrando seus quadros, buscando no mercado os técnicos para a solução de pontos específicos, não tendo custos elevadíssimos com a manutenção permanente desses técnicos em seus quadros. Seu pessoal e equipamentos devem ser os mais modernos no mercado. A terceirização, mediante contratação de serviços, ao invés da criação de cargos de natureza efetiva, deve ser a tônica para o atendimento da maioria das necessidades de pessoal da agência $^{20}$.

\section{Receita do órgão regulador}

A fim de garantir a autonomia das agências reguladoras, definidas no Brasil como autarquias especiais, se estabeleceu mecanismo de atribuição de receitas sem

19 Informativo STF no 144, de 29 a 30/03/99 e 05 a 09/04/99. Brasília: Supremo Tribunal Federal, 1999.

20 Tratamos da validade da opçāo pela terceirização em Desestatização - Privatização, concessōes $e$ terceirizaçōes, $2^{a}$ ed. 1999, págs 243 e ss. 
que os recursos tenham que transitar pelo Erário; foi instituída uma "taxa de regulação" ou "taxa de fiscalização dos serviços concedidos ou permitidos", devida pelo concessionário ou permissionário de serviços diretamente à agência; calcula-se o valor da taxa com base em percentual sobre o proveito obtido com a concessão ou permissão.

A agência, com isso, não depende de recursos orçamentários, mas, em compensação, se submete à crítica de ser custeada pelo sujeito fiscalizado.

LÚCIA HELENA SALGADO ${ }^{21}$ aborda a polêmica acerca do custeio da regulação pelo fornecedor do bem ou serviço regulado. $O$ argumento inicial é no sentido de que a regulação seria "adquirida" pela indústria e desenhada e operada primariamente para seu benefício (Stigler), ao que se contrapõe a inteligência de que nenhum interesse econômico captura de forma exclusiva o corpo regulatório. Ele deriva um equilíbrio em que o político maximizador de utilidade aloca benefícios entre grupos otimamente. Assim, dado que consumidores podem oferecer votos ou dinheiro em troca de algum afastamento do equilíbrio de cartel, a proteção pura do produtor não será, em geral, a estratégia política dominante (Peltzman).

De fato, se não houver eqüidistância entre os interesses sob apreciação da agência, toda a política regulatória se enfraquece, submetendo-se ao risco de futuros governantes proporem a extinção do órgão ou entidade.

\subsection{Natureza jurídica da taxa de regulação}

O fato de a "taxa de regulação" ou "taxa de fiscalização dos serviços públicos" ter sido criada por lei levou a inúmeros entendimentos no sentido de se tratar de um tributo cujo fato gerador é o exercício do poder de polícia, definido no art. 145, II, CF e no art. 78 do Código Tributário Nacional ${ }^{22}$. Afinal, trata-se de prestação pecuniária compulsória, que não constitui sanção de ato ilícito, instituída por lei e cobrada mediante atividade administrativa vinculada (CT, art. $3^{\circ}$ ).

Tendo como base de cálculo a receita auferida pela concessionária, seria vedada tal previsão, eis que as taxas não podem ter base de cálculo típica de impostos ${ }^{23}$.

21 A economia política da ação antitruste. São Paulo: Singular, 1998, págs. 84 a 86.

22 Parecer $n^{2}$ 05/98-WD, da lavra do Procurador do Estado do Rio de Janeiro WALDEMAR DECACHE, exarado em 15.12.98 no Processo Administrativo ${ }^{2}$ E-04/887.145/98, provocado por consulta da ASEP - Agência Reguladora de Serviços Públicos concedidos do Estado do Rio de Janeiro.

23 O Informativo STF $\mathrm{n}^{\circ}$ 137, de 10.02.99 divulgou a seguinte decisão: “ Taxa e Critérios de Incidência — indeferida medida liminar em ação direta ajuizada pela Confederação Nacional do Transporte - CNT, contra a Taxa de Fiscalizaçāo e Controle dos Serviços Públicos Delegados, instituída pelo Estado do Rio Grande do Sul (Lei estadual 11.073/97, regulamentada pelo Decreto 39.228/98), cujo valor, a ser pago pelos Delegatários dos Serviços Públicos prestados no referido Estado, é definido de acordo com o faturamento do contribuinte, conforme tabela de incidência progressiva. À primeira vista, o Tribunal, por maioria de votos, afastou a alegação de ofensa ao art. $145, \S 2^{\circ}$, da CF (" As taxas não poderão ter base de cálculo própria de impostos."), uma vez que o referido tributo nāo incide sobre o faturamento das empresas contribuintes, mas apenas utiliza-o como critério para a incidência de taxas fixas. Vencido o Min. Néri da Silveira, relator, que, considerando relevante a tese de inconstitucionalidade sustentada pela 
É certo que o Código Tributário Nacional estabelece que poder de polícia é a atividade da administração pública que, limitando ou disciplinando direito, interesse ou liberdade, regula a prática de ato ou abstenção de fato, em razão de interesse público concernente ao exercício de atividades econômicas dependentes de concessão ou autorização do Poder Público; na expressão "concessão" estaria a base da polêmica.

Tal atividade estaria, assim, imposta à Administração por força de lei, criando para o particular a obrigação de pagamento. Não teria sido conferida uma faculdade à Administração para cobrar ou não tal prestação, mas sim uma ordem concernente ao dever de serem ressarcidas as despesas com a fiscalização dos serviços.

Logo, num primeiro exame, poder-se-ia cogitar da inexistência de dúvida quanto ao caráter tributário da prestação devida sob o nome de "taxa" (ressaltando que a taxa de regulação do Estado do Rio Grande do Sul está sub judice no Supremo Tribunal Federal).

Este não foi, contudo, um entendimento pacífico. A ilustre Procuradora do Estado do Rio de Janeiro VERA LÚCIA KIRDEIKO ${ }^{24}$, esclarece que a referida "taxa" tem natureza contratual, não sendo cobrada em função de um serviço público prestado pelo Estado às concessionárias nem, tampouco, pelo exercício do poder de polícia, caracterizado este, valendo-se da lição de CELSO ANTONIO BANDEIRA DE MELLO, pelas manifestações impositivas da Administração limitadoras da liberdade, distinguindo-se de outras manifestações impositivas da Administração porque "se originam de um título jurídico especial relacionador da Administração". Visa, pois, a remunerar os serviços de fiscalização do cumprimento das normas contratuais ou legais pertinentes. E o faz amparada na lição sempre atualizada de HELY LOPES MEIRELLES ${ }^{25}$, que expõe que:

"É comum ainda nos contratos de concessão de serviços públicos a fixação de um preço, devido pelo concessionário ao concedente a título de remuneração dos serviços de supervisão, fiscalização e controle de execução do ajuste a cargo deste último."

Ainda em defesa de seu posicionamento, a ilustre parecerista invocou a lição de GERALDO ATALIBA, que entendia que a remuneração devida por empresas concessionárias ao agente fiscalizador não tinha forma ou figura de tributo. Nessa mesma linha se posicionou o Egrégio Superior Tribunal de Justiça ${ }^{26}$. Tal inteligência,

autora da ação - no sentido de que a variaçāo do valor da taxa em funçāo do faturamento do contribuinte equiuivaleria à adoçāo desse faturamento como base de cálculo do tributo, descaracterizando sua natureza jurídica, transformando-a em imposto -, deferia o pedido de medida liminar. ADIUnMC I.948-RS, rel. Min. Néri da Silveira 4.2.99.

24 Parecer $s / n^{2}$, exarado em 01.12.98 no Processo administrativo $\mathrm{n}^{\mathcal{Q}}$ E-04/887.145/98, provocado por consulta da ASEP - Agência Reguladora de Serviços Públicos concedidos do Estado do Rio de Janeiro. 25 Direito Administrativo Brasileiro, 1988, pág. 235, apud Parecer $\mathrm{s} / \mathrm{n}^{\mathrm{Q}} \mathrm{de} 01.12 .98 \mathrm{PG}-3$, da Procuradora do Estado VERA LÚCIA KIRDEIKO.

26 Embargos de Divergência no Recurso Especial no 863 (Reg. 93.0015592-0), tendo como Relator o Exmo. Sr. Ministro José de Jesus Filho, com ementa no sentido de que "É legítima a cobrança pela Empresa Metropolitana de Transportes Urbanos de São Paulo S/A - EMTU pelos serviços de gerenciamento às empresas permissionárias de transporte coletivo de passageiros. na Região Metropolitana de 
contudo, não passou despercebida ao Procurador do Estado do Rio de Janeiro WALDEMAR DECACHE ${ }^{27}$, que sustentou que a hipótese seria distinta porque havia mera autorização em decreto para a cobrança e não, como aqui em exame, lei impondo tal obrigação.

Submetida a controvérsia ao Procurador do Estado do Rio de Janeiro JOÃO GUILHERME SAUER ${ }^{28}$, para decisão, foi firmada a conclusão, afinal vistada pelo Procurador-Geral do Estado do Rio de Janeiro, no sentido de que não se trata do exercício do poder de polícia, nos seguintes termos:

"Assim, a Administração, quando exerce o Poder de Polícia, como que corrige, preventiva ou repressivamente, os rumos de direitos e liberdades potencialmente contrários ao interesse público, mesmo quando ela, Administração, não seja parte do espectro de relações engendradas por esses direitos e liberdades.

Daí o caráter geral ou genérico da Polícia Administrativa: objetos dela são todos os direitos e liberdades, cujo exercício possa contrariar o interesse público.

Ora, quando a Administração celebra contrato ou pratica ato de delegação a terceiros de atividade a ela atribuída pelo ordenamento — como soem ser os serviços públicos —, a atividade delegada está, por definição, vocacionada a satisfazer o interesse público. $\mathrm{O}$ interesse público colimado é o mesmo que presidiu à celebração do contrato ou à prática do ato. Trata-se, aqui, não da contraposição da Administração aos rumos natural e potencialmente indesejáveis do exercício da atividade, mas sim, de colaboração entre ela e o particular em fazer com que esse exercício se faça de acordo com os termos da delegação - tanto mais quanto a responsabilidade pelo bom ou mau desempenho da atividade para com seus destinatários é do próprio delegante. O problema é, pois, de fazer cumprir o contrato, poder que cabe às partes de qualquer contrato, inclusive a Administração, só que, quanto a esta, se verifica uma posição de predominância que não está presente nas relações entre particulares."

De fato, data venia dos entendimentos em contrário, assiste razão à conclusão de que a taxa de regulação não é um tributo; não há prestação de serviço público que é executado pelos concessionários e permissionários - nem exercício de poder de polícia.

A atividade administrativa, segundo DIOGO DE FIGUEIREDO MOREIRA NETO, se classifica em poder de polícia, prestação de serviços públicos, ordenamento econômico e ordenamento social.

O poder de polícia constitui, em apertadíssima síntese, restrição, limitação ou condicionamento da liberdade privada em prol do interesse coletivo. Tal regramento da liberdade privada se dá pelo comando de polícia, pelo consentimento de polícia, pela fiscalização de polícia e pela sanção de polícia.

Sāo Paulo." Do corpo do acórdão se extrai a conclusão de que "A EMTU não presta serviço público e muito menos às empresas transportadoras de passageiros. $O$ que faz é policiar a atividade de tais empresas."

27 Parecer $\mathrm{n}^{2}$ 05/98, cit.

28 Visto exarado em 05.02.99 no citado Processo administrativo $\mathrm{n}^{0}$ E-04/887.145/98, aprovado pelo Exmo. Sr. Procurador-Geral do Estado do Rio de Janeiro, Dr. FRANCESCO CONTE em 05.02.99. 
Ora, na hipótese em exame, está-se diante de atividade administrativa diversa, isto é, da prestação de serviços públicos de forma descentralizada para particular, mediante desestatização na modalidade de concessão ou permissão de serviços públicos.

Como nas demais atividades administrativas, a prestação de serviços públicos se desenvolve em três momentos, a saber, o planejamento, a execução e o controle. É deste último que se trata a hipótese, cabendo ao contratado, por encargo contratual, previamente autorizado por lei, custear as despesas com a fiscalização e controle da execução dos serviços.

Ao contrário do que ocorre no poder de polícia, quando o Estado atua sobre uma esfera de liberdade cujo titular é o particular, nos serviços públicos essa titularidade já pertence ao Estado, não tendo o particular que os presta, sob normas e controle do Estado, qualquer liberdade a ser restrita pelo exercício do poder de polícia. O poder-dever do Estado de atender o interesse público, orientado pelo princípio da eficiência, já restringe a liberdade do próprio administrador público quanto às técnicas de prestação do serviço.

Ademais, a atividade regulatória é distinta da fiscalizatória, já que esta pressupõe normas, diretrizes, decisões arbitrais fixadas por aquela.

Não se tratando de exercício do poder de polícia, não há que se falar em tributo para o seu custeio ${ }^{29}$.

\section{Contratos celebrados pela agência de regulação}

No Brasil, as agências reguladoras são autarquias especiais, destacando-se por certas peculiaridades ligadas ao processo de investidura e de perda de mandato dos seus dirigentes, sem, contudo, se afastarem dos limites e obrigações inerentes à Administração Pública, em especial os previstos no art. 37 da Constituição Federal, que, em seu inciso XXI, trata das licitações e contratos administrativos.

Portanto, tais entidades estão obrigadas à regra geral de licitação, tanto para as suas atividades-fim como para as suas atividades instrumentais; seus contratos, em ambos os casos, são contratos administrativos, regidos pelo direito público, dotados das prerrogativas que se caracterizam como cláusulas exorbitantes.

A legislação sobre licitações e contratações administrativas para as entidades da administração pública direta, autárquica e fundacional está prevista no art. 22 , XXVII, da Constituição, que preconiza a submissão a "normas gerais".

Ocorre que, se todas as agências se submetem às mesmas normas gerais de licitação (atualmente, a Lei $\mathrm{n}^{\circledR} 8.666 / 93$ ), inconstitucional seria, num primeiro exame,

29 O CTN menciona autorizaçōes e concessōes. Cabe, no entanto, lembrar que as autorizações, ao removerem obstáculos legais em hipóteses em que não se ataca o interesse geral, sāo manifestações de poder de polícia, assim como há atos unilaterais de concessāo, como, por exemplo, as de outorga da exploração de minérios - CF, art. 176 e DL 227 - que constituem atividades econômicas. Nāo se referiu, pois, aos serviços públicos sob concessão ou permissão. 
a Lei $\mathrm{n}^{\mathrm{o}} 9.472$, de 16.07.97, que, em seus artigos 55 a 59, prevê procedimento licitatório distinto para a Agência Nacional de Telecomunicações - ANATEL, que poderia adotar, para os contratos que não se refiram a obras e serviços de engenharia, os procedimentos de "consulta" e de "pregão", que são bastante diversos daqueles previstos na Lei $\mathrm{n}^{\circ} 8.666 / 93$ (concorrência, tomada de preços, convite, concurso e leilão).

Na verdade, o art. $37, \S 8^{0}$ da Constituição Federal admite que a lei amplie a autonomia de órgãos e entidades da Administração Pública, o que respaldaria tal dispositivo, que representa valioso avanço no tema das licitações.

\section{Fiscalização sobre a agência de regulação}

Como entidade integrante da Administração Pública, a agência reguladora fica sujeita aos termos do art. 70 da Constituição Federal, que submete as pessoas físicas e jurídicas gestoras de bens e recursos públicos ao controle financeiro interno e externo, prevendo-se, assim, a participação do Tribunal de Contas na apreciação dos valores apresentados.

Logo, não se inclui na competência dos órgãos de controle financeiro o exame de ações ou omissões que não impliquem em gestão de recursos. Confira-se a lição de LUIS ROBERTO BARROSO ${ }^{30}$ :

"Nada, rigorosamente nada, no texto constitucional o autoriza a investigar o mérito das decisões administrativas de uma autarquia, menos ainda de uma autarquia com as características especiais de uma agência reguladora. Não pode o Tribunal de Contas procurar substituir-se ao administrador competente no espaço a ele reservado pela Constituição e pelas leis. $O$ abuso é patente. Aliás, nem mesmo o Poder Legislativo, órgão coadjuvado pelo Tribunal de Contas no desempenho do controle externo, poderia praticar atos dessa natureza...

É fora de dúvida, assim, que o Tribunal de Contas não pode avançar sua atividade fiscalizatória sobre a atividade fim da agência reguladora, em clara violação ao princípio fundamental da Separação dos Poderes. Logo, não pode o Tribunal de Contas questionar decisões político-administrativas da ASEP-RJ nem tampouco requisitar planilhas e relatórios expedidos pela agência ou por concessionário, que especifiquem fiscalização e procedimentos adotados na execução contratual. Somente lhe cabe informar-se sobre aquilo que possa ser legitimamente objeto de sua apreciação."

Quanto ao controle externo das decisões das agências reguladoras pelo Poder Judiciário, já se expôs que, no Direito brasileiro, se adotou o modelo inglês de controle jurisdicional da Administração Pública. Os atos das entidades da Administração Pública, por força do princípio da jurisdição una, se submetem à apreciação

30 Parecer $\mathrm{n}^{\mathrm{Q}}$ 05/98-LRB, do Gabinete do Exmo. Sr. Procurador Geral do Estado, exarado em 10.12.98, no Processo Administrativo $n^{2}$ E-14/35.468/98. 
do Poder Judiciário. ao contrário do modelo francês. do contencioso administrativo, que prevê uma instância própria para o controle dos feitos da Fazenda Pública.

É claro que, como dito, o princípio é da Separação de Poderes, não podendo o Judiciário interferir nos juízos privativos da entidade legalmente competente para a fiscalização e regulação de setores da economia.

Afinal, a lei que cria tais entidades lhes assegura autonomia administrativa, técnica e financeira.

Igualmente não deve caber controle administrativo pela via do recurso hierárquico impróprio, admitindo-se que a decisão da agência reguladora possa ser revista ou modificada por um agente político (como um Ministro ou Secretário de Estado, por exemplo). Isso retiraria toda a independência da entidade e a segurança dos investidores, que ficariam, assim, sujeitos a critérios políticos (e, porque não dizer, demagógicos) de julgamento.

\section{Processo administrativo}

A Lei $\mathrm{n}^{0}$ 9.784, de $29.01 .99^{31}$ estabelece "normas básicas sobre o processo administrativo no âmbito da Administração Federal direta e indireta, visando, em especial, a proteção dos direitos dos administrados e ao melhor cumprimento dos fins da Administração", incluídas, pois, as agências reguladoras, que se revestem da personalidade de autarquia. $O$ centro das preocupações foi o interesse dos administrados, destinatários das ações do Estado em qualquer de suas formas (daí ter incluído, ainda, os atos dos Poderes Legislativo e Judiciário entre os destinatários).

Foram destacados os "princípios da legalidade, finalidade, motivação, razoabilidade, proporcionalidade, moralidade, ampla defesa, contraditório, segurança jurídica, interesse coletivo e eficiência", os critérios de "atuação conforme a lei e o Direito", de "atendimento a fins de interesse geral", de "objetividade no atendimento do interesse público" de "atuação segundo padrões éticos de probidade, decoro e boa-fé", "divulgação oficial dos atos", "adequação entre meios e fins", etc... (previstos no art. $2^{\circ}$ da citada lei); devem ser observadas as normas que impōem "direitos e deveres dos administrados", "desenvolvimento do processo", "competência, impedimentos e suspeição", "dever de decidir e motivação", que visam, justamente, a dar aplicabilidade aos princípios constitucionais e legais a que estão sujeitas as entidades estatais.

Expõe ODETE MEDAUAR ${ }^{32}$ que

"O processo administrativo encontra respaldo explícito e direto no inciso LV do art. $5^{9}$ da Constituição Federal, que impõe o contraditório e a ampla defesa em

31 Que teve uma Comissão elaboradora do anteprojeto que the deu origem composta de nomes como Caio Tácito. Diogo de Figueiredo Moreira Neto, Odete Medauar. Almiro Couto, Maria Sylvia Zanella Di Pietro.

32 Processo Administrativo - contornos atuais. São Paulo: Cultural Paulista, 1998, pág. 23. 
situações de controvérsia ou conflitos de interesse ante a Administração Pública e em situações em que se atribuem a pessoas condutas suscetíveis de sanção.

O processo administrativo representa garantia de direitos, tanto no atinente ao indivíduo considerado isoladamente quanto sob o prisma dos direitos coletivos e difusos. Além do mais, associa-se à concepção de Estado democrático de direito e aos princípios constitucionais da Administração, como corolário e veículo de sua expressão.

Daí a preocupação contemporânea de se dotar os países de uma lei geral de processo administrativo, explicitadora dos direitos básicos que o informam, para que seus desdobramentos surjam nítidos para os cidadãos, os servidores públicos e as autoridades."

Além dos processos de físcalização típicos da função regulatória, cabe citar, ainda, como exemplos de processos administrativos aplicáveis a essas entidades a licitação, o processo disciplinar, o processo de concurso público, instrumentos do cotidiano das ações dessas entidades.

Registre-se que o chamado "processo de expediente" não se submete a tais regras, já que se trata de mera autuação que tramita informalmente pela Administração contendo documentos para a prática de um ato.

Além dos processos que previnem litígios tipicamente administrativos, como a ação popular e o mandado de segurança, há, ainda, a provocação de processos administrativos para a prevenção de litígios típicos da atividade regulatória, como as reclamações de consumidores, as reclamações contra abusos de poder econômico e outras questões com fornecedores e contratados da agência, as reclamações por lesão ou ameaça de lesão ao meio ambiente.

A regra, no entanto, é a ausência de uma formalidade, salvo expressa previsão legal (art. 22), desde que atendidos os princípios, em especial, da ampla defesa, do contraditório e da motivação.

Cabe citar, como sugestão de rito procedimental, que, constatada a irregularidade, será lavrado Auto de Infração, em três vias, pelo Comissário-Geral, destinando-se a primeira via ao autuado e as demais à formação do processo administrativo; não dependendo de Auto de Infração ou de notificação a apuração decorrente de reclamação de usuário.

O Auto de Infração conterá o nome e endereço do autuado, o fato constitutivo da infração, a disposição legal ou contratual em que se fundamenta a autuação, a penalidade a ser aplicada e, quando for o caso, o prazo para correção da irregularidade e a assinatura da autoridade competente.

O autuado tomará ciência do Auto de Infração por carta registrada ou por qualquer outro meio de comunicação válida, seguindo o instrumento como notificação para cumprimento de suas exigências ou apresentação de defesa, no prazo previsto em lei ou contrato.

Ocorrendo defesa, a autoridade, no prazo da lei ou do contrato, embasado em parecer técnico, proferirá decisão, mantendo a sanção aplicada, total ou parcialmente, ou cancelando-a. A multa será paga pelo infrator no prazo assinalado na decisão, contado da notificação para recolhimento, devendo, ainda, se for o caso, se promover 
a eliminação das situações ensejadoras da penalidade, sob pena de serem estabelecidas novas sanções, incluída a caducidade da concessão.

Da decisão deve caber recurso sem efeito suspensivo, já que o ato administrativo tem presunção de legalidade e legitimidade, devendo ser prolatada decisão motivada.

Dentro das características de preservar a equiidistância das partes, a agência deve assegurar transparência de seus atos, julgando seus processos em sessões públicas. Formado o processo, é sorteado o conselheiro relator, que restituirá o processo junto à Câmara, daí resultando uma Deliberação, que deve ser tomada em sessão pública para a qual sejam intimadas as partes interessadas.

\section{As agências no âmbito federal}

As agências federais do petróleo, telecomunicações e energia atuam como poder concedente por descentralização administrativa da União outorgada por leis federais, observando as características de independência acima mencionadas ${ }^{33}$.

\subsection{Petróleo}

No caso do Petróleo, a Lei $\mathrm{n}^{9} 9478 / 97$, que criou a Agência Nacional do Petróleo $^{34}$, trata da implementação das políticas, da regulação do upstream (produ-

33 Dispensamo-nos de uma abordagem mais detalhada sobre cada uma delas para evitar repetições desnecessárias do que já foi exposto em Desestatização, cit., págs. 136 a 139, 162 a 177, 193 a 203 e 167 a 170 , que tratam das concessōes e regulaçāo nesses setores.

34 Lei $n^{2}$ 9.478, de 06.08.97 (DOU 07.08.97) - "Dispõe sobre a Política Energética Nacional, as Atividades Relativas ao Monopólio do Petróleo, Institui o Conselho Nacional de Política Energética e a Agência Nacional do Petróleo, e dá outras providências. (...) Art. $8^{\mathfrak{0}}-$ A ANP terá como finalidade promover a regulação, a contratação e a fiscalização das atividades econômicas integrantes da indústria do petróleo, cabendo-lhe: I - implementar, em sua esfera de atribuições, a política nacional de petróleo e gás natural, contida na política energética nacional, nos termos do Capítulo I desta Lei, com ênfase na garantia do suprimento de derivados de petróleo em todo o território nacional e na proteção dos interesses dos consumidores quanto a preço, qualidade e oferta dos produtos; II - promover estudos visando à delimitação de blocos, para efeito de concessāo das atividades de exploração, desenvolvimento e produção; III - regular a execução de serviços de geologia e geofísica aplicados à prospecção petrolífera, visando ao levantamento de dados técnicos, destinados à comercialização, em bases não-exclusivas; IV — elaborar os editais e promover as licitações para a concessão de exploração, desenvolvimento e produção, celebrando os contratos delas decorrentes e fiscalizando a sua execução; $\mathrm{V}$ - autorizar a prática das atividades de refinação, processamento, transporte, importação e exportação, na forma estabelecida nesta Lei e sua regulamentação; VI - estabelecer critérios para o cálculo de tarifas de transporte dutoviário e arbitrar seus valores, nos casos e da forma previstos nesta Lei; VII - fiscalizar diretamente, ou mediante convênios com órgãos dos Estados e do Distrito Federal, as atividades integrantes da indústria do petróleo, bem como aplicar as sanções administrativas e pecuniárias previstas em lei, regulamento ou contrato; VIII - instruir processo com vistas à declaração de utilidade pública, para fins de desapropriaçāo e instituição de servidão administrativa, das áreas necessárias à exploração, desenvolvimento e produção de petróleo e gás natural, construção de refinarias, de dutos e de terminais; IX - fazer cumprir as boas práticas de conservação e uso racional do petróleo, dos derivados e do gás natural e de preservação do 
ção) e downstrean (refino, transporte e distribuição), e, com a flexibilização, novas indústrias vão participar desse segmento industrial, que tem como características o alto risco, recursos não renováveis e a integração vertical das empresas.

A missão da ANP nesse novo contexto é promover a regulação, contratação e fiscalização em todo setor da indústria ("do poço ao posto"), estimulando a competição, com a entrada de novos competidores e capitais; cabe-lhe aumentar a arrecadação, supervisionar o poder de mercado (em conjunto com o Ministro da Justiça e Ministério da Fazenda).

Sua atuação é colegiada e com sessões deliberativas públicas, aí incluída a alteração, em audiências públicas, de normas que afetem o setor.

\subsection{Telecomunicações}

No campo das telecomunicações, a globalização da economia, a evolução tecnológica e a velocidade das mudanças no mercado e nas necessidades dos consumidores forçaram um redimensionamento do setor das telecomunicações em todo o mundo, sendo, inclusive, objeto de acordo específico no âmbito da Organização Mundial do Comércio, por força do qual cada um dos Estados-membros obrigou-se a assegurar aos prestadores de serviço de qualquer outro Estado-membro acesso às suas redes públicas de transporte, o que implica, por exemplo, a interconexão de circuitos privados. O Brasil aderiu a essa lista através do Protocolo $n^{0} 4 / 97^{35}$.

Com a Emenda Constitucional $n^{0} 8 / 95$, foi flexibilizado o monopólio das telecomunicações, prevendo-se sede constitucional para o órgão regulador, cujas características só vieram a ser implementadas com o advento da Lei no 9.472, de 16.07.97, que criou a ANATEL em moldes bastante semelhantes aos órgãos reguladores americano e colombiano ${ }^{36}$. Antes dela, a Lei $n^{2} 9.295$, de 19.07.96, cometera a função

meio ambiente; $\mathrm{X}$ - estimular a pesquisa e a adoção de novas tecnologias na exploração, produção, transporte, refino e processamento; XI - organizar e manter o acervo das informações e dados técnicos relativos às atividades da indústria do petróleo; XII - consolidar anualmente as informações sobre as reservas nacionais de petróleo e gás natural transmitidas pelas empresas, responsabilizando-se por sua divulgação; XIII - fiscalizar o adequado funcionamento do Sistema Nacional de Estoques de Combustíveis e o cumprimento do Plano Anual de Estoques Estratégicos de Combustíveis, de que trata o art. $4^{\complement}$ da Lei $\mathrm{n}^{2}$ 8.176, de 8 de fevereiro de 1991; XIV - articular-se com os outros órgãos reguladores do setor energético sobre matérias de interesse comum, inclusive para efeito de apoio técnico ao CNPE; XV - regular e autorizar as atividades relacionadas com o abastecimento nacional de combustíveis, fiscalizando-as diretamente ou mediante convênios com outros órgāos da Uniāo, Estados, Distrito Federal ou Municípios.

35 Sobre o tema, ver UMBERTO CELLI JÚNIOR. A nova organização dos serviços na lei geral de telecomunicações . Boletim de Direito Administrativo $n^{2}$ 08/98. NDJ:Sāo Paulo, 1998, pág. 512 a 518.

36 Lei n 9.472/97(DOU 17.07.97) - "Dispōe sobre a organização dos serviços de telecomunicaçōes, a criaçāo e funcionamento de um órgāo regulador e outros aspectos institucionais, nos termos da Emenda Constitucional $\mathrm{n}^{2} 8$, de 1995. (...) Art. $8^{2}$ - Fica criada a Agência Nacional de Telecomunicaçōes, entidade integrante da Administração Pública Federal indireta, submetida a regime autárquico especial e vinculada ao Ministério das Comunicaçōes, com a funçāo de órgāo regulador das telecomunicações, com sede no Distrito Federal, podendo estabelecer unidades regionais. $\S 1^{\varrho}$ A Agência terá como órgão máximo o 
regulatória. em caráter provisório. ao Ministro das Comunicações, até que fosse criado o órgão regulador.

\subsection{Energia Elétrica}

A Lei $n^{9}$ 9.427, de 26.12.96, criou a Agência Nacional de Energia Elétrica ANEEL, que veio a substituir o DNAEE - Departamento Nacional de Águas e Energia Elétrica, encarregada de exercer o poder concedente tanto do serviço público de energia elétrica como do uso dos potenciais de energia elétrica ${ }^{37}$.

Conselho Diretor, devendo contar, também, com um Conselho Consultivo, uma Procuradoria, uma Corregedoria, uma Biblioteca e uma Ouvidoria, além das unidades especializadas incumbidas de diferentes funçōes $\$ 2^{Q} \mathrm{~A}$ natureza de autarquia especial conferida à Agência é caracterizada por independência administrativa, ausência de subordinação hierárquica, mandato fixo e estabilidade de seus dirigentes e autonomia financeira. Art. $9^{\circ}-\mathrm{A}$ Agência atuará como autoridade administrativa independente, assegurando-se-lhe, nos termos desta Lei, as prerrogativas necessárias ao exercício adequado de sua competência.". A Agência Nacional de Telecomunicaçōes está regulamentada pelo Decreto $n^{\mathcal{Q}} 2.338$, de 07/10/1997 (DOU de 08/10/1997, em vigor desde a publicação).

37 Lei $\mathrm{n}^{\mathrm{Q}}$ 9.427, de 26.12.96 (DOU 27.12.96) - "Institui a Agência Nacional de Energia Elétrica ANEEL, disciplina o regime das concessōes de serviços públicos de energia elétrica e dá outras providências. (...) Art. $3^{2}-$ Além das incumbências prescritas nos artigos 29 e 30 da Lei $n^{\circ} 8.987$, de 13 de fevereiro de 1995, aplicáveis aos serviços de energia elétrica, compete especialmente à ANEEL: I implementar as políticas e diretrizes do governo federal para a exploração da energia elétrica e o aproveitamento dos potenciais hidráulicos, expedindo os atos regulamentares necessários ao cumprimento das normas estabelecidas pela Lei $\mathrm{n}^{2}$ 9.074, de 7 de julho de 1995 ; II — promover as licitações destinadas à contratação de concessionárias de serviço público para produção, transmissão e distribuição de energia elétrica e para a outorga de concessão para aproveitamento de potenciais hidráulicos; III - definir o aproveitamento ótimo de que tratam os $\$ \S 2^{2}$ e $3^{2}$ do art.5 $5^{2}$ da Lei $n^{2} 9.074$, de 7 de julho de 1995; IV - celebrar e gerir os contratos de concessão ou de permissão de serviços públicos de energia elétrica, de concessão de uso de bem público, expedir as autorizaçōes, bem como fiscalizar, diretamente ou mediante convênios com órgãos estaduais, as concessões e a prestação dos serviços de energia elétrica; $\mathrm{V}$ - dirimir, no âmbito administrativo, as divergências entre concessionárias, permissionárias, autorizadas, produtores independentes e autoprodutores, bem como entre esses agentes e seus consumidores; VI - fixar os critérios para cálculo do preço de transporte de que trata o § $6^{\varrho}$ do art. 15 da Lei $\mathrm{n}^{\mathrm{Q}} 9.074$, de 7 de julho de 1995, e arbitrar seus valores nos casos de negociação frustrada entre os agentes envolvidos; VII - articular com o órgão regulador do setor de combustíveis fósseis e gás natural os critérios para fixação dos preços de transporte desses combustiveis, quando destinados à geraçāo de energia elétrica, e para arbitramento de seus valores, nos casos de negociação frustrada entre os agentes envolvidos. VIII - estabelecer. com vistas a propiciar concorrência efetiva entre os agentes e a impedir a concentração econômica nos serviços e atividades de energia elétrica, restriçōes, limites ou condiçōes para empresas, grupos empresariais e acionistas quanto à obtenção e transferência de concessões, permissões e autorizaçōes, à concentração societária e à realização de negócios entre si; IX - zelar pelo cumprimento da legislação de defesa da concorrência, monitorando e acompanhando das práticas de mercado dos agentes do setor de energia elétrica. na forma a ser estabelecida em regulamento. $X$ - fixar as multas administrativas a serem impostas aos concessionários, permissionários e autorizados de instalaçōes e serviços de energia elétrica, observado o limite, por infração, de dois por cento do faturamento, ou do valor estimado da energia produzida nos casos de autoprodução e produção independente, correspondente aos últimos doze meses anteriores à lavratura do auto de infraçāo. $\S 1^{\circ}$ No exercício da competência prevista nos incisos VIII e IX deste artigo. a ANEEL deverá articular-se com a Secretaria de Direito Econômico do Ministério da Justiça. $\$ 2^{2}$ Sem prejuízo de outras sanções contratuais ou regulamentares, bem como da 
Pela Resolução no 296, de 11.09.98. a ANEEL estabeleceu os procedimentos para a descentralização de atividades complementares pelos Estados e Distrito Federal, que poderão fiscalizar, punir e determinar padrões de qualidade das concessionárias, exigindo-se que suas agências demonstrem capacitação técnica para tanto. Sobre o tema, observa PEDRO DUTRA ${ }^{38}$ que a competência da ANEEL é atribuída por lei e só por outra lei pode ser alterada; isso não se confunde com a possibilidade de firmar convênios operacionais, desde que as agências estaduais sejam dotadas da mesma autonomia que a ANEEL. Do contrário, ocorre a mesma possibilidade já aventada acima, de o concessionário opor-se à nova forma de regulação diversa da realidade de autonomia considerada no momento em que decidiu realizar os investimentos (princípio da segurança jurídica).

\subsection{Transportes}

Estuda-se a criação de uma Superintendência de Infra-Estrutura de Transportes - SIT, autarquia vinculada ao Ministério dos Transportes, que substituirá o DNER, a Comissão Federal de Transportes Ferroviários e a Empresa Brasileira de Planejamento de Transportes. E ficará responsável pela operação e supervisão de ferrovias, hidrovias e rodovias. Ao lado dela haverá a ANT - Agência Nacional dos Transportes, que atuará na regulação e fiscalização, no moldes das demais agências federais.

O transporte aéreo deverá ficar a cargo de órgão distinto, que abrigará o Departamento de Aviação Civil e a Infraero.

É prevista, ainda, a criação de um fundo com receitas tributárias vinculadas de um imposto seletivo sobre combustíveis.

A proposta pecará pelo fato de criar mais tributos incidindo sobre a produção, fugindo ao padrão da não vinculada da receita de impostos, e por fazer agência depender de tributo, quando a regra é desvinculá-la de receitas transferidas pelo Tesouro através da cobrança da taxa de regulação.

\section{As agências no âmbito estadual}

Os programas estaduais de desestatização têm estimulado as concessões e o surgimento dos órgãos reguladores, que, no entanto, não têm, como no plano federal, a função de poder concedente. A maioria delas é das chamadas agências multissetoriais (sem especialização, com competência para todos os serviços). Por outro lado,

encampação ou desapropriaçāo de bens associados à concessão, permissāo ou autorização, estas mediante prévia autorizaçāo do poder concedente, a ANEEL levará em conta, na determinação do valor da multa, a gravidade da falta."

38 A fiscalização dos serviços públicos privatizados. Rio de Janeiro: Gazeta Mercantil, 20.10.98, pág. A-3. 
o distanciamento dos problemas das agências federais exige uma descentralização para Agências de Regulação dos Estados, o que deve ter previsão legal para, através de convênio, receber competências; reduz-se a influência das empresas fiscalizadas sobre a agência, reduz custos e facilita o aprendizado.

\subsection{Estado do Rio de Janeiro}

No Estado do Rio de Janeiro, relata o ilustre Procurador do Estado SÉRGIO NELSON MANNHEIMER ${ }^{39}$ que a Lei $n^{0} 2.686$, de 13.02.97, alterada pela Lei $n^{0}$ 2752/97, instituiu a ASEP-Agência Reguladora de Serviços Públicos, com competência para regular e fiscalizar, de forma ampla, as concessões ou permissões nas quais o Estado figure como concedente ou permitente.

Caracteriza-se por ser, como várias agências estaduais, multissetorial, encarregada da regulação de diversas áreas, tais como energia (gás), transportes (metrô, barcas, trens e rodovias) e saneamento, além de receber delegação federal para exercer parcialmente a fiscalização na área de energia.

Destaca, ainda, o parecerista que:

"A criação da ASEP-RJ incorporou, basicamente, elementos colhidos de outras legislações, especialmente a formatação de agências reguladoras européias e americanas, as chamadas utilities commissions. O conceito que motivou então o Poder Executivo, quando do encaminhamento do Projeto de Lei que veio a se transformar na Lei $n^{9} 2.686 / 96$, ao menos em tese, girava em torno da idéia de se criar uma agência independente e autônoma, que pudesse atuar como se estivesse no centro de um triângulo regular, onde os respectivos vértices eqüidistantes seriam ocupados pelo Poder Concedente, pelos Usuários e pelos Concessionários, dirimindo de forma imparcial os conflitos que entre estas surgissem."

Ocorre que o novo Governo do Estado do Rio de Janeiro, empossado em 01.01.99, houve por bem propor a extinção da ASEP e apresentar projeto de lei de criação de duas novas agências reguladoras, a AINFRA, para regular e fiscalizar os serviços de energia e infra-estrutura, e a ATRANSPOR, reguladora e fiscalizadora de transportes públicos. Sobre o tema, o ilustre Procurador do Estado SÉRGIO LUIZ BARBOSA NEVES ${ }^{40}$, no exercício do cargo de Subprocurador-Geral do Estado, opinou que:

"Não fossem estas novas agências, seria de sugerir-se mesmo a manutenção da ASEP- RJ em face da imprescindibilidade de um ente especializado na regulação e na fiscalização dos serviços concedidos e permitidos."

Relativamente à AINFRA, o ilustre Procurador SÉRGIO NELSON MANNHEIMER, com a autoridade de ter acompanhado a elaboração do projeto de lei que criou

39 Parecer $\mathrm{n}^{\mathrm{Q}}$ 04/99-SNM, da Procuradoria de Serviços Públicos, integrante da estrutura da Procuradoria Geral do Estado do Rio de Janeiro, exarado em 21.01.99, no Processo Administrativo n² E-12/229/99. 40 Parecer no 03/99-SPG-SLBN, do Gabinete do Exmo. Sr., Subprocurador-Geral do Estado do Rio de Janeiro, exarado em 27.01.99, no Processo Administrativo no E-14/30.331/99, fls. 19. 
a ASEP e a política de regulação do Estado, tendo sido um de seus primeiros Conselheiros, bem percebeu que a proposta estabeleceu a possibilidade de recurso das decisões da Agência a uma Junta Recursal composta por membros do Conselho de Secretários a ser instituído pelo Poder Executivo através de decreto, anotando que:

"A existência de um recurso externo estabelece, na prática, uma instância superior à agência, com poderes para rever suas decisões. A inclusão de dispositivo desta ordem encerra uma nova política de regulação, que envolve considerações acerca da autonomia que se pretende conferir ao órgão regulador. De toda sorte, se tal posição de fato prevalecer, conviria que a própria lei estabelecesse a composição e as linhas gerais de funcionamento do Conselho de Secretários de Estado, que, pela sua importância, mereceria maior estabilidade do que aquela que lhe seria outorgada por decreto, alterável a qualquer momento por simples ato do Chefe do Poder Executivo."

Já quanto à criação da $\mathrm{ATRANSPOR}^{41}$, assume esta nova agência as funções outrora exercidas pelo DETRO, autarquia estadual que fora preservada pela Lei $n^{0}$ 2.686/96, a qual exercia a fiscalização dos transportes na forma da Lei $n^{9} 1.221 / 87$; é prevista, agora, uma Câmara de Transporte Rodoviário. A exemplo do que se previu para a AINFRA, igualmente se tratou de um recurso externo.

A exemplo da ASEP, tanto a AINFRA como a ATRANSPOR funcionarão mediante cobrança de uma "taxa de regulação", cuja natureza jurídica ainda é discutida, se tributo ou preço público.

As agências estaduais não têm o poder concedente; nascem com a finalidade de, a partir de um contrato de concessão (com os condicionamentos nele previstos), exercer o poder regulatório e fiscalizador, funcionando como instância administrativa definitiva. Não formula políticas nem cria exigências que não sejam tradução das obrigações qualitativas e quantitativas definidas na lei e no contrato.

Cumpre citar, ainda, no Estado do Rio de Janeiro, a existência de uma Agência Metropolitana de Transportes Urbanos do Estado do Rio de Janeiro - AMTU-RJ, cuja criação se almejou através de convênio entre o Estado e o Município de Niterói, admitindo a adesão de qualquer município da Região Metropolitana, tendo objetivos sociais, de assegurar oportunidades de emprego, ecológicos, de redução da poluição, urbanísticos, econômicos e políticos, objetivando a liberdade de opção na movimentação das pessoas, cabendo-lhe propor planos, regulamentos, política tarifária, apuração e acompanhamento de custos.

A AMTU tem um conselho deliberativo composto pelos Secretários de Transportes do Estado e do Município do Rio de Janeiro, o Presidente do DETRO Departamento de Transportes Rodoviários, Presidentes da Superintendência Municipal de Transportes, da Companhia do Metropolitano - METRÔ, da Companhia Fluminense de Trens Urbanos - FLUMITRENS, e representantes do Conselho

41 Anteprojeto de Lei analisado no Parecer $n^{2}$ 03/99-SNM, da Procuradoria de Serviços Públicos, integrante da estrutura da Procuradoria Geral do Estado do Rio de Janeiro, exarado em 20.01.99, no Processo Administrativo $n^{2}$ E-12/228/99 
Estadual de Trânsito - CETRAN, da Federação das Empresas de Transporte FETRANSPOR, do BNDES, dos Municípios da Região Metropolitana. Há, ainda, previsão de um comitê executivo e uma comissão técnica. Não são previstos recursos no convênio, os quais dependerão de estudos para as dotações.

É de se ressaltar que a ASEP-RJ não absorveu os serviços de transportes coletivos, que continuaram sob a fiscalização do DETRO - Departamento de Transportes Rodoviários.

Tanto a AMTU como o DETRO não correspondem ao modelo regulatório moderno que aqui se analisa (assim como, no âmbito federal, a Comissão Federal de Transportes Ferroviários - COFER; cujo Regimento Interno foi aprovado pela Portaria $\mathrm{n}^{\mathrm{Q}} 362$, de 20.08.97 do Ministro dos Transportes, encarregada de decidir recursos sobre a aplicação de penalidades).

\subsection{Estado de São Paulo}

Em São Paulo, optou-se por agências especializadas. Pela Lei Complementar $\mathrm{n}^{0} 833$, de 17.10.97 foi criada a Comissão de Serviços Públicos de Energia - CSPE, autarquia vinculada à Secretaria de Estado de Energia, com a finalidade de regular, controlar e fiscalizar a qualidade do fornecimento dos serviços públicos, os preços, tarifas e demais condições de atendimento aos usuários de tais serviços, coibindo os abusos e discriminações.

Sua remuneração é composta, entre outras receitas, pelo produto da arrecadação da taxa de fiscalização paga pelos titulares de concessões, permissões e autorizações de serviços de energia, calculada mediante aplicação de um limite máximo de cinco décimos por cento da receita bruta auferida.

Tem como órgão superior um conselho Deliberativo, composto de um Comissário-Geral (em regime de dedicação exclusiva e sujeito a prestação de contas), um representante da Fundação de Proteção e Defesa do Consumidor-PROCON, um representante da sociedade civil, indicado pelos Conselhos de Consumidores (art. 13 da Lei Federal no 8.631, de 04.03.93), dois representantes das empresas prestadoras de serviços públicos de energia no Estado, sendo um das empresas de serviços locais de gás canalizado, e outro das empresas de energia elétrica, dois representantes dos trabalhadores nas referidas empresas, um representante dos servidores da Comissão, um representante da FIESP, um representante da Federação do Comércio do Estado de São Paulo e três membros de livre escolha do Governador. É, afinal, quase uma auto-regulação de interesses dada a presença dos agentes regulados no conselho fiscalizador, no que difere da linha adotada nas agências federais e na ASEP, do Rio de Janeiro.

É previsto um mandato de quatro anos, permitida uma única recondução, ocorrendo a perda do mandato em caso de condenação transitada em julgado por crime doloso, por improbidade administrativa, impugação de contas pelo Tribunal de Contas ou ausência não justificada a reuniões.

Há um Comissariado, que é órgão de execução, composto pelo Comissário-Geral e dois Comissários-Chefes, nomeados em comissão pelo Governador do Estado, 
dentre cidadãos com notória capacidade técnica e administrativa em suas respectivas áreas de atuação.

É ainda previsto um quadro de servidores provido mediante concurso público, o que não está na linha mais moderna. que prevê, como dito, uma flexibilidade.

A Lei foi regulamentada pelo Decreto $n^{\underline{0}} 43.036$, de 14.04 .98 , que trata das competências dos órgãos administrativos e dos procedimentos, inclusive no que concerne aos requisitos do auto de infração e dos recursos.

\subsection{Estado do Ceará}

A Lei $n^{\circ}$ 12.786, de 30.12.97 instituiu a Agência Reguladora de Serviços Públicos Delegados do Estado do Ceará - ARCE, autarquia sob regime especial, vinculada à Procuradoria Geral do Estado, dotada de autonomia orçamentária, fínanceira, funcional e administrativa, com poder de direção, regulação e fiscalização sobre serviços públicos delegados.

O poder regulatório da ARCE será exercido com a finalidade última de atender o interesse público, mediante normatização, planejamento, acompanhamento, controle e fiscalização das concessões e permissões, que obedecerá aos seguintes princípios:

I - justiça e responsabilidade no exercício do poder regulatório;

II - honestidade e equiidade no tratamento dispensado aos usuários, às diversas entidades reguladas e demais instituições envolvidas na prestação ou regulação dos serviços públicos delegados;

III - imparcialidade, evidenciada pela independência de influências políticas de setores públicos ou privados que possam macular a credibilidade dos procedimentos decisórios subjacentes ao exercício do poder regulatório;

IV - capacidade de desenvolvimento técnico, conforme as necessidades de mercado e as políticas estabelecidas pelo poder concedente.

Seus objetivos fundamentais são:

I - promover e zelar pela eficiência econômica e técnica dos serviços públicos delegados, submetidos à sua competência regulatória, propiciando condições de regularidade, continuidade, segurança, atualidade, universalidade e modicidade das tarifas;

II - proteger os usuários contra o abuso de poder econômico que vise à dominação dos mercados, à eliminação da concorrência e ao aumento arbitrário dos lucros;

III - fixar regras procedimentais claras, inclusive em relação ao estabelecimento, revisão, ajuste e aprovação de tarifas, que permitam a manutenção do equilíbrio econômico-financeiro dos contratos de concessões e termos de permissões de serviços públicos;

IV - atender, através das entidades reguladas, às solicitações razoáveis de serviços necessárias à satisfação das necessidades dos usuários;

$\mathbf{V}$ - promover a estabilidade nas relações entre o poder concedente, entidades reguladas e usuários; 
VI - estimular a expansão e a modernização dos serviços delegados, de modo a buscar a sua universalização e a melhoria dos padrões de qualidade, ressalvada a competência do Estado quanto à definição das políticas de investimento;

VII - livre, ampla e justa competição entre as entidades reguladas, devendo o Poder Público atuar para propiciá-la, bem como corrigir os efeitos da competição imperfeita.

Serão de sua competência:

I - regulação econômica dos serviços públicos delegados, mediante o estabelecimento de tarifas ou parâmetros tarifários que reflitam o mercado e os custos reais de produção, de modo a, concomitantemente, incentivar os investimentos privados e propiciar a razoabilidade e modicidade das tarifas aos usuários;

II - regulação técnica e controle dos padrões de qualidade, fazendo cumprir os critérios tecnológicos e normas qualitativas, conforme estabelecidos em contrato de concessão, termo de permissão, Lei ou pelos órgãos competentes, de forma a garantir a continuidade, segurança e confiabilidade da prestação de serviço público;

III - atendimento ao usuário, compreendendo o recebimento, processamento e provimento de reclamações relacionadas com a prestação de serviços públicos delegados, conforme a regulamentação.

IV - zelar pelo fiel cumprimento da legislação, dos contratos de concessão e termos de permissão de serviços públicos sob a sua competência regulatória, podendo, para tanto, determinar diligências junto ao poder concedente e entidades reguladas, e ter amplo acesso a dados e informações;

V - implementar as diretrizes estabelecidas pelo poder concedente em relação à concessão e permissão de serviços sujeitos à competência da $\mathrm{ARCE}$;

VI - dirimir, em âmbito administrativo, conflitos entre o poder concedente, entidades reguladas e usuários;

VII - outorgar concessões e permissões, quando o poder concedente delegar à ARCE tal atribuição por meio de instrumento específico, e sempre em obediência à legislação vigente;

VIII - fiscalizar, diretamente ou mediante contratação de terceiros, os aspectos técnico, econômico, contábil, financeiro, operacional e jurídico dos contratos de concessão e termos de permissão de serviços públicos, aplicando, se for o caso, diretamente as sanções cabíveis, entre as quais, suspensão temporária de participação em licitações, intervenção administrativa e extinção da concessão ou permissão, em conformidade com a regulamentação desta Lei, e demais normas legais e pactuadas;

IX - incentivar a competitividade nos diversos setores sujeitos à sua regulação;

$\mathbf{X}$ - prestar consultoria técnica relativamente aos contratos de concessões e termos de permissões, mediante solicitação do poder concedente.

\subsection{Estado do Rio Grande do Sul}

A Lei Estadual n 10.931 , de 09.01.97 criou a ACERGS - Agência Estadual de Regulação dos Serviços Públicos Delegados do Rio Grande do Sul, de natureza autárquica, dotada de autonomia financeira, funcional e administrativa, com os mesmos objetivos de assegurar a observância dos princípios da prestação dos serviços 
públicos. fiscalizando, normatizando, fixando tarifas em diversos setores, tais como saneamento, energia elétrica, rodovias, telecomunicações, portos e hidrovias, irrigação, transportes intermunicipais, aeroportos, gás canalizado e inspeção de segurança veicular.

Sua estrutura básica prevê um Conselho Superior, uma Diretoria-Geral, três Departamentos, a saber, de Qualidade dos Serviços, de Tarifas e de Estudos Econômico-Financeiros e de Assuntos Jurídicos.

O Conselho Diretor é composto por sete membros aprovados pela Assembléia Legislativa do Estado, que tem, também, o poder de destituí-los. São três membros de livre indicação do Governador do Estado, um representante do quadro funcional, indicado pelo Governador a partir de listas tríplices elaboradas em eleição secreta entre os servidores, dos representantes dos consumidores e um representante dos concessionários, permissionários e autorizatários de serviços públicos.

\subsection{Estado de Sergipe}

Propôs-se no Sergipe a criação da ASES - Agência Reguladora de Serviços Concedidos do Estado de Sergipe, autarquia vinculada à Secretaria de Estado do Planejamento e da Ciência e Tecnologia, com a finalidade de exercer o poder de regular e fiscalizar as concessões e permissões de serviços públicos, com características semelhantes às da ASEP no Rio de Janeiro (tais como taxa de regulação, mandato fixo dos dirigentes, somente sendo destituídos nas hipóteses de condenação transitada em julgado por crime doloso, por improbidade administativa, impugnação de contas pelo Tribunal de Contas ou ausência não justificada a reuniões, prevendo-se a participação da Procuradoria Geral do Estado na fiscalização dessas situações).

\section{Experiências de Regulação no Direito Comparado}

Entre as experiências amealhadas no direito comparado ${ }^{42}$, no México, cabe citar a Comisión Federal de Competência (CFC), responsável pela área de petróleo e telecomunicação.

Na Inglaterra, segundo relatam JOSÉ CARLOS DE SOUZA BRAGA, ANDRÉ MEDICI e MARTA ARRETCHE ${ }^{43}$, toda a regulação do sistema de saneamento passou a ser feita por órgãos do nível central de governo. É o caso da National Rivers Authorithy, do Office of Water Services e do Drinking Water Inspectorate, que têm atuado não apenas como agentes de fiscalização dos produtos do novo sistema, mas também como organismos normativos e orientadores da ação das empresas de saneamento. Essas agências não são necessariamente atreladas ao governo e têm muita autonomia para tomar decisões e realizar estudos para o aprimoramento do processo de ordenamento do sistema no contexto da privatização.

42 Ver BENJÓ NETO, ob. cit. págs. 12 e ss.

43 Novos horizontes para a regulaçāo do sistema de saneamento no Brasil. Revista de Administração Pública, vol. $29 \mathrm{n}^{0} 1.1995$, pág. 115 a 148. 
Relatam, ainda, que a França. detentora de um modelo mais descentralizado, optou por realizar concessões privadas e contratos de gestão de serviços através dos quais o governo eliminaria os controles administrativos e burocráticos e passaria somente a acompanhar os resultados a serem atingidos, a partir de metas acordadas.

Ainda na Europa, cite-se a Entidade Reguladora do Setor Elétrico e, o mesmo setor, na Argentina, é regulado por Entes Reguladores de Eletricidade - Argentina ( $E N R E$ ), com grandes influências na estruturação e competência da ANEEL.

$O$ órgão regulador de energia da Argentina simula a existência de um competidor, aplicando-se a Lei de Marco Regulatório (do final de 1991).

No caso de transporte de distribuição de energia, também definido como serviço público, o órgão regulador determina preço e qualidade e previne a prática de abuso de posição dominante.

Pelo "princípio do livre acesso", também adotado no Brasil, conforme preconizado no HILMER REPORT, os grandes consumidores podem comprar energia no mercado ${ }^{44}$.

A geração, como agora no Brasil (Lei no 9.074/95 e 9.648/98), opera em mercado de concorrência e não tem a característica de serviço público; todos os geradores recebem um preço uniforme em cada local de entrega, calculando com base no custo econômico do sistema.

Os distribuidores devem oferecer a totalidade de energia que lhe demandam, não podendo sequer alegar a falta; isto é, garantindo o abastecimento com um adequado esquema de preços-tarifas (baseado na Lei da oferta e da procura) estimulando os investimentos.

As ações de empresas que se dediquem ao transporte e distribuição devem ser nominativas e não endossáveis; cabem fusões, desde que autorizadas pelo órgão regulador. O proprietário de ações num segmento é controlado para evitar que controle empresas de outro segmento.

Como no Brasil, antes da transformação do setor a totalidade da atividade era exercida pelo Estado, em integração vertical de empresas, inexistindo uma adequada distribuição de tarifas; a regulação e a gestão se confundiam nas empresas; daí decorreu um déficit, pois as tarifas eram fixadas para objetivos outros (conter a inflação), sem relação com o custo do serviço; isto resulta em ineficiente gestão administrativa e técnica e incapacidade de atender a expansão do setor ${ }^{45}$.

Para a transformação foi necessário segmentar o setor em geração, transporte e distribuição, adaptar as empresas estatais, segmentá-las e privatizá-las, instituindo um "marco regulatório", e um órgão regulador (para cumprir a Lei n. ${ }^{\circledR} 2.4065$ ), instaurando-se um modelo no qual o êxito está ligado à qualidade dos projetos em lugar da capacidade de influir nas medidas do Governo.

44 Tratamos do tema no estudo sobre "Monopólios e concentrações no setor público", ainda não publicado. apresentado em março de 1999 no Curso de Doutorado em Direito Econômico da Universidade Gama Filho.

45 Nos processos de privatizaçāo. o único requisito exigido foi o de apresentar um operador técnico, para apregar experiência no manejo do negócio. 
O Mercado tem na CAMMESA - Companhia Administradora do Mercado Elétrico, sem fins de lucro, a entidade encarregada de administrar o "Mercado Mayorista" (despacho econômico, preços, horários). Tem como sócios o Estado (Secretaria de energia, com Poder de Veto), Geradores, Distribuidores, Transportadores e Grandes Usuários (que têm liberdade de contratação).

Ficam, assim, atenuados os efeitos do monopólio, com livre acesso a redes, regulação das condições de prestação de função técnica, liberdade de contratação de energia entre geradores.

Dentre as funções do Regulador destaca-se a de ditar normas sobre segurança, procedimentos técnicos, medição e fatura (bases de cálculo), controle e uso de medidores, interrupção e reconexão, qualidade, organizar um regime de audiências públicas, fiscalizar a execução dos contratos de concessão e examinar a caducidade, cessão, substituição dos contratos.

A participação do usuário na Argentina se dá pelas várias associações, que têm atuação junto aos diretórios de órgãos reguladores (em Portugal por indicação de instituto de defesa do consumidor). A Constituição de 1994 não define o critério de participação do usuário no diretório dos entes reguladores, mas assegura tal direito; o comum é o usuário participar das audiências públicas; do contrário, haveria risco de corporativismo; o usuário lesado pode reclamar à empresa prestadora ou ao departamento de atendimento aos usuários do órgão regulador.

\section{Conclusões}

O Programa de Reforma do Estado decorre da incapacidade de o setor público prosseguir como principal agente financiador do desenvolvimento econômico, sendo imperiosa a necessidade de atração de capitais privados para os setores de interesse público.

Esses investimentos só ocorrerão se houver "lucratividade" e "segurança", palavras mágicas para o empresário num regime de livre iniciativa.

Não resta dúvida que a abertura ao capital estrangeiro e a flexibilização dos monopólios são instrumentos que inauguram um cenário de competitividade e de possibilidade de lucro ao setor privado.

A segurança, por sua vez, só será alcançada com estabilidade das regras e autonomia dos agentes encarregados de sua aplicação, que não podem ficar aos sabores da predileção política e pressionados por critérios demagógicos de decisão, mas, sim, por fatores técnicos e financeiros que equilibrem os interesses entre fornecedores, consumidores e poder público. Daí a relevância da criação de agências reguladoras dotadas de autonomia, nos moldes colhidos no direito comparado, escolhendo-se os dirigentes pelo critério do mérito, adotando-se a forma autárquica.

A Lei de Concessão de Serviços Públicos e as leis que criaram agências reguladoras atendem a essa realidade de transformação econômica e devem exercer notável papel de integração das normas contratuais, eis que tais instrumentos, de longo prazo (para maturação dos investimentos sem sacrifício dos consumidores) não podem prever todas as circunstâncias inovadoras e incidentes ao longo de sua 
execução. Tais normas buscaram atenuar as prerrogativas materializadas nas cláusulas exorbitantes que caracterizam os contratos administrativos e que deixam, não raro, inseguro o investidor quanto às possibilidades de alteração e extinção unilateral desses pactos.

A extinção de agências, a quebra de contratos e a encampação de serviços por motivos políticos aniquilam essa sinalização positiva aos investidores, podendo retardar, em muito, o processo de desenvolvimento nacional, além de resultar em prejuízos ao Erário, com indenizações aos concessionários e com o pagamento de remuneração aos conselheiros, que têm direito a percebê-la pelo restante do prazo de seus mandatos.

Os dirigentes são agentes políticos, com processo especial de nomeação e investidura; se extinto o órgão, tem direito à remuneração. As demais funções da entidade devem ser atendidas, conforme o caso, com terceirizações, evitando-se, em funções não decisórias ou de controle, a criação de cargos permanentes na sua estrutura.

A agência reguladora de serviços públicos não exerce poder de polícia, mas, sim, fiscalização do cumprimento do contrato de concessão. Portanto, a receita arrecadada junto aos concessionários não tem natureza tributária, devendo ser evitada a dependência de recursos transferidos pelo Erário, a fim de manter a autonomia do órgão.

Quando atuar como poder concedente, a agência pode se submeter à arbitragem, desde que o litígio não envolva interesses indisponíveis.

A regulação constitui passo relevante na Reforma do Estado e deve ser estimulada como mecanismo de atração de investimentos e garantia dos consumidores. 